Al-Fikra: Jurnal IImiah Keislaman, Vol. 16, No. 2, Juli - Desember, 2017 (233 268)

\title{
STRATEGI MEMBANGUN KESADARAN PENERAPAN SYARI'AH ISLAM MELALUI DAKWAH EKSTRAPARLEMENTER
}

\author{
${ }^{1}$ EDI SABARA MANIK, ${ }^{2} \mathrm{HASANUDDI}$ \\ ${ }^{1,2}$ Program Pascasarjana IImu Politik, Universitas Riau \\ Pembebas_sejati@yahoo.co.id
}

\begin{abstract}
Islam is the perfect religion that governs the relationship between man and his god (ibadah), man with his fellow man (muamalah) and relationship with himself. This rule is what is meant by Shari'ah. However, today the Muslims can only practice the rules that are ibadah, while muamalah that is implemented today is not in accordance with the Shari'ah. Therefore, there should be a da'wah in openness to Muslims so that they are aware of the problem of the application of shari'ah in all kinds of life. One of the most powerful and open movement of da'wah in the struggle for Islamic Shariah is Hizbut Tahrir Indonesia (HTI). This movement is a non-Minstream movement that was established on Al-Quds Palestine and Indonesia in the 1980s through a cleric from Hizb ut-Tahrir, DR. Abdurrahman Al-Baghdadi. The strategy of hizbut tahrir in carrying out its da'wah activities by opening up, accepting everyone to become a cadre, hizbut tahrir approach from technocrats, students, academics, intellectuals and even they also do pandekatan entrepreneurs who can accept their da'wah idea. Its da'wah strategy through culture and structural or political, this is the strategy of da'wah from other Islamic mass organizations. However, his political strategy is an extraparalementer.
\end{abstract}

Keyword; Strategy, Politics, Hizb ut-Tahrir

\section{A. Latar Belakang}

Until a few years ago, most Islamist groups considered the notion of establishing a new Caliphate a utopian goal. Now, anincreasing number of people consider it a serious objective.

"Hingga beberapa tahun yang lalu, sebagian besar kelompok Islam menganggap upaya penegakan Khilafah yang baru adalah tujuan yang utopis. Sekarang, semakin bertambah orang yang mempertimbangkan pendirian kembali Khilafah sebagai tujuan yang serius".( Zayno Baran, 2005)

Geliat dakwah Islam saat ini, Alhamdulillah dengan izin Allah 
Edi Sabara Manik, Hasanuddin; Strategi Membangun Kesadaran Penerapan

Syari'ah Islam Melalui Dakwah Ekstraparlementer

SWT, seruan dan ajakan kepada syariah yang akan diterapkan dalam sistem khilafah sudah semakin menggelora, masyarakat juga semakin merindukan tegaknya syari'ah. Hal ini tergambar dari Survei oleh PPIM UIN Syahid Jakarta, menunjukkan masyarakat yang menginginkan syariah pada tahun 2001 sebesar 61\%, tahun 2002 sebesar 71\%, dan pada tahun 2003 meningkat menjadi sebesar $75 \%$. Selain itu, pernah dilakukan sebuah survei oleh GMNI (Gerakan Mahasiswa Nasionalis Indonesia) pada tahun 2006 untuk mengetahui pandangan hidup apa yang dipilih mahasiswa bagi kehidupan berbangsa dan bernegara di Indonesia. Respondennya adalah para mahasiswa perguruan tinggi terkemuka di Indonesia, yaitu Universitas Indonesia (UI), Institut Teknologi Bandung (ITB), Universitas Gadjah Mada (UGM), Universitas Airlangga (Unair), dan Universitas Brawijaya (Unibraw). Hasilnya menunjukkan sebagian besar mahasiswa memilih Syariah Islam (80 \%), sementara 15,5\% mahasiswa memilih Sosialisme, dan hanya 4,5\% mahasiswa yang memilih Pancasila.(Kompas, 4 Maret 2008)

Survei lain pernah dilakukan
SEM Institute (Shariah
Management and Economic Institute), Jakarta, pada bulan Maret 2008. Survei dilakukan di 26 kota Indonesia dengan 1052 orang responden. Ketika kepada para responden ditanyakan, "Setujukah Anda dengan penerapan Syariah Islam?" ternyata sebagian besar masyarakat (83\%) menyetujui penerapan Syariah Islam. Mereka juga ditanya, "Yakinkah Anda bahwa Syariah Islam dapat membawa kemaslahatan dan satusatunya solusi bagi masalah bangsa?"Jawabannya adalah sebagian besar (84\%) menyatakan yakin.Kepada responden juga ditanyakan, "Setujukah Anda dengan pernyataan,'Khilafah adalah bentuk sistem politik dan pemerintahan dalam Islam?"Jawabannya,sebagian

besar responden (74\%) menyatakan setuju (SEM, 2008)

Selanjutnya Survey yang dilakukan YouGov terungkap hasil yang cukup mengejutkan, dua perlima (40\%) dari mahasiswa Muslim yang disurvei (1400 mahasiswa) mendukung diterapkannya Syariah menjadi undang-undang bagi Muslim Inggris. Sementara itu sepertiga $(33 \%)$ dari mahasiswa Muslim yang disurvei mendukung diterapkannya kekhalifahan di seluruh dunia yang didasarkan pada hukum Syari'ah. Mayoritas (58\%) dari anggota aktif Masyarakat Islam kampus mendukung ide ini.

Oleh karena itu, tidak berlebihan kalau Ketua Dewan Duma (Parlemen Rusia), Mikael Boreyev, dalam buku Rusia Imperium Ketiga memprediksikan bahwa pada tahun 2020 mayoritas negara-negara di dunia akan mengalami kehancuran, dan nanti hanya akan ada lima negara besar yakni: Rusia, yang telah menggabungkan Eropa kedalamnya; Cina, yang akan mendominasi negara-negara Asia Timur dengan kekuatan militer dan ekonominya; Khilafah Islamiyah, yang akan membentang dari Jakarta hingga Tangier dan mayoritas daerah Afrika; dan Konfederasi yang 
Al-Fikra: Jurnal Ilmiah Keislaman, Vol. 16, No. 2, Juli - Desember, 2017 (233 268)

menggabungkan benua Amerika Utara dan Amerika Selatan. Boreyev memprediksi India juga mungkin menjadi negara besar jika ia mampu menghadapi kekuatan Islam yang meliputinya (AI Waie XI, 2010). NIC (National Inteligent Council) yang berpusat di Washington dalam The Global Future Mapping 2020, diantaranya memperkirakanakan berdirinya The New Islamic Chaliphate (Khilafah Islam yang Baru). Indonesia memiliki 240.271.522 penduduk Islam dan merupakan penduduk Islam terbesar di dunia. Mereka telah berperan besar dalam sejarah bangsa ini mulai dari banyaknya pejuang Islam yang menduduki peran penting dalam kemerdekaan Indonesia, sertifikat halal MUI yang menjadi acuan di 33 Negara, hingga kebangkitan Islam juga akan dimulai dari Indonesia. Dalam salah satu hadits berikut;

Artinya; "Dari Tsauban ra, dia berkata, telah bersabda Rasulullah SAW, akan datang Panji-panji Hitam dari sebelah timur, seolaholah hati mereka kepingankepinganbesi. Barang siapa mendengar tentang mereka, hendaklah datang kepada mereka dan berbaiatlah kepada mereka sekalipun merangkak diatas salju. (dikeluarkan dari Al Hasan bin Sofyan dari Al-hafiz Abu Nuaim) (dari kitab Al-Hawi lil fatawa oleh Imam Sayuti). Ada yang berpendapat bahwa kata timur itu dimaksudkan kepada Asia Tenggara, di Asia Tenggara yang paling banyak muslimnya adalah Indonesia".

$\begin{array}{llr}\text { Hizbut } & \text { Tahrir merupakan } \\ \text { sebuah pergerakan politik } \\ \text { intenasional yang menasbihkan }\end{array}$

dirinya sebagai salah satunya pergerakan yang fokus pada tujuan untuk melanjutkan kehidupan Islam dengan tegaknya syariah dibawah institusi khilafah Islam.Hizbut Tahrir yang didirikan oleh Taqiyuddin AnNabbani di al-Quds Pelestina telah memiliki jaringan di 48 negara diberbagai belahan dunia. Dan aktifberoperasi di wilayah Timur Tengah,Afrika, Asia Tengah, Asia Selatan,Asia Tenggara, dan di negara-negaraBarat. Dalam pergerakannya Hizbut Tahrir menggunakan sistem komando untuk mengorganisir sistem dakwah dan politik yang dilaksanakan oleh seluruh kader yang tersebar diseluruh dunia.

Organisasi Hizbut Tahrir berpandangan Islam telah membatasi bentuk kekuasaan yang tunggal, yaitu pemerintah yang menjalankan hukum sesuai dengan apa yang telah diturunkanAllah SWT. Dalam pandangan yang sama Islam juga telah menetapkan sekaligus membatasi bentuk sistem pemerintahan dengan sistem khilafah dan menjadikannya sebagai satu-satunya sistem pemerintahan bagi daulah Islami.

Hizbut Tahrir (HT) memiliki Motto besar yang sering didengung-dengungkan ; La 'izzata Illa bil Islam, wa la Islama Illa bi Syari'ah, wa la Kaffatan li Tatsbiqi Syari'ata Illa Bi Daulati Khilafah, yang artinya Tiada kemulian tanpa Islam, Tiada Islam tanpa Syari'ah dan Tiada kesempurnaan penerapan Syariah tanpa Daulah Khilafah. Begitu juga dengan Hizbut Tahrir yang ada di luar negerimemiliki Slogan yang terdapat dalam spanduk Hizbut Tahrir dalam setiap aksinya; Save the World with Syariah and 
Edi Sabara Manik, Hasanuddin; Strategi Membangun Kesadaran Penerapan

Syari'ah Islam Melalui Dakwah Ekstraparlementer

Khilafah. Ada tiga rangkaian misi gerakan yang tidak bisa dipisahkan satu sama lainnya. Islam bagi Hizbut Tahrir sebuah ideologi politik yang harus di terapkan dalam system pemerintah dengan cara memberlakukan atau formalisasi syari'at Islam. Sistem Politik yang didasarkan pada Syari'ah itu sendiri yang bisa ditegakkan dalam naungan Daulah Khilafah Islamiyah.

Kemunculan gerakangerakan tersebut tidak terlepas dari kondisi politik pasca Orde Baru yang sedang mengalami transisi demokrasi dari tahun 1998-2013, yang ditandai dengan terjadinya political distrust dan social distrust. Hizbut Tahrir Chapter Kampus Pekanbaru memberikan 10 catatan sepanjang tahun 2012 terkait peran Negara dalam menjalankan fungsinya sebagai ri'ayah "pengatur" urusan rakyat, yang menunjukkan lemahnya dan ketidak berdayaannya dalam menangani; Ekonomi, politik, maupun sosial budaya. Pertama kekayaan alam dijarah asing. Kedua, korupsi yang tidak berhenti bahkan semakin meluas dan menggurita (dari korupsi pejabat Negara sampai korupsi Negara). Ketiga persoalan buruh yang tak kunjung selesai. Keempat, buramnya hukum di Indonesia, disamping hukumnya yang amburadul dan penegak hukumnya juga bengkok. Kelima proses legislasi yang sarat dengan kepentingan kapitalisme dan merugikan kepentingan rakyat. Keenam konflik horizontal yang semakin meluas yang mencerminkan kegagalan konsep Bhineka Tunggal Ika. Ketujuh meningkatnya kenakalan remaja tepatnya tindakan kriminal remaja sebagai cerminan kegagalan system pendidikan nasional. Kedelapan, isu terorisme dan program deradikalisasi yang menjadikan Islam dan umat Islam sebagai musuh. Kesembilan penghinaan terhadap Nabi Muhammad saw yang terus berulang. Kesepuluh gejolak dunia Islam yang semakin memanas.

Ormas dan berbagai kekuatan-kekuatan masyarakat menjadi lebih dominan dalam menguasai wacana public daripada Negara. Hampir semua organisasi massa melakukan upaya penggalangan kekuatan untuk mempengaruhi kebijakan politik. Kuatnya tekanan masyarakat membuat Negara tidak mampu menyelesaikan konflik yang muncul sehingga antar kekuatan kelompok saling berhadapan satu sama lain dan saling unjuk kekuatan. Radikalisasi gerakan massa kemudian menjadi fenomena yang melekat pada ormas-ormas, termasuk ormas agama.

Gerakan Hizbut Tahrir didasari oleh semangat untuk melanjutkan kembali kehidupan Islam, dan melanjutkan dakwah Islam keseluruh penjuru dunia, dengan mengajak kaum Muslim untuk kembali hidup secara Islami di Darul Islam. Seluruh aktivitas kehidupan didalamnya diatur sesuai dengan hukum-hukum syara'. Pandangan hidup yang akan menjadi pusat perhatiannya adalah halal dan haram, dibawah naungan Daulah Islamiyah, yaitu Daulah Khilafah, yang dipimpin oleh seorang Khalifah yang diangkat dan di bai'at oleh kaum Muslim untuk di dengar dan ditaati, dan agar menjalankan 
Al-Fikra: Jurnal Ilmiah Keislaman, Vol. 16, No. 2, Juli - Desember, 2017 (233 268)

pemerintahannya berdasarkan Kitabullah dan Sunnah Rasul-Nya. Juga untuk mengemban risalah Islam ke seluruh dunia dengan dakwah dan jihad.

Hizbut Tahrir juga bertujuan untuk membangkitkan kembali umat Islam dengan kebangkitan yang benar, melalui pola pikir yang cemerlang. Hizbut Tahrir berusaha untuk mengembalikan posisi umat Islam kemasa kejayaan dan kemuliaannya, mengambilalih kendali Negara-Negara dan bangsa-bangsa di dunia, dan agar kembali menjadi Negara Super Power di dunia, seperti yang telah terjadi di masa silam, dan memimpinnya sesuai dengan hukum Islam. Tujuan Hizbut Tahrir lainnya adalah menyampaikan Hidayah (petunjuk syari'at) bagi umat manusia, memimpin umat Islam untuk menentang ide-ide dan system perundang-undangan kufur maupun kekufuran itu sendiri secara menyeluruh, sehingga Islam dapat menyelimuti seluruh dunia (Anonim, 2010)

Gerakan Islam ideologis melakukan gerakan perlawanan pada dua bentuk; (1) Perlawanan Pemikiran atau perang Pemikiran "Shira'ul Fikri", (2) perlawanan Politik "Kifahu Siyasi”. Perlawanan pemikiran atau perang pemikiran biasanya dilakukan untuk mengcounter pemikiran-pemikiran yang dianggap tidak sejalan atau merusak ideology Islam, dalam hal ini Hizbut Tahrir menjadikan pemikiran yang berasal dari barat seperti Sekulerisme, liberalisme, kapitalisme, Sosialismekomunisme, demokrasi, nasionalisme dan isme-isme lainnya sebagai pemikiran yang meracuni umat Islam. Perlawanan dan perjuangannya dilakukan dengan dua pendekatan, pertama pendekatan politik diwujudkan dalam bentuk jama'ah atau komunitas seperti organisasi Politik, ataupun kelompokkelompok gerakan yang dijadikan kendaraan untuk melawan tatanan politik yang ada, dan untuk mewujudkan ideology dalam tataran praktis.Kedua, pendekatan gerakan social (Social movement). Pendekatan ini mengasumsikan bahwa sebuah fenomena sosial dapat dikatakan sebagai gerakan social jika dilakukan secara kolektif, terjadi secara berulangulang, berlangsung dalam waktu yang lebih lama, terorganisir, menyentuh kepentingan anggota masyarakat, sebagai bentuk aksireaksi atas kebijakan pemerintah dan mendapatkan respon yang beragam baik dari pihak yang pro ataupun kontra (Sunyoto, 2005).

Hizbut Tahrir dikategorikan sebagai gerakan politik Islam.Dikatakan sebagai gerakan Politik karena makna "Hizbut Tahrir" itu sendiri adalah partai pembebasan. Membebaskan manusia dari penyembahan kepada manusia kepada penyembahan Tuhannya manusia yakni Allah SWT. Bentuk penyembahan secara totalitas kepada Allah SWT adalah dengan menerapkan Syariat Islam dalam seluruh aspek kehidupan di bawah institusi Islam yakni Khilafah Islam.Ini berarti penghapusan hukum-hukum buatan manusia sekaligus bentuk pemerintahannya. Dan hal ini juga ditegaskan di kitab Hizbut Tahrir yang dikeluarkan secara resmi; bahwa Hizbut Tahrir adalah Partai politik yang berideologi Islam. Politik 
merupakan aktivitasnya, dan Islam adalah mabda-nya (Anonim, 2010).

Hizbut Tahrir sebagai gerakan sosial karena merupakan sebuah organisasi yang terorganisir, melibatkan masyarakat sebagai anggota gerakannya maupun basis gerakannya, sekaligus menjadikan masyarakat sebagai jalan untuk meraih kekuasaan an Thariqul Ummah.

Hizbut Tahrir sebagai sebuah gerakan politik Islam dan juga gerakan sosial, banyak aspek yang melingkupi gerakan Hizbut Tahrir. Misalnya, sejarah gerakan, visi dan misi gerakan, keorganisasian, kepemimpinan, perilaku politik gerakan, ideology, tahapantahapan gerakan dan strategi atau metode gerakan, afiliasi gerakan serta mobilisasi gerakan.

Pada dekade 1980-an, beberapa organisasi radikal Internasional mulaitumbuh dan berkembang di Indonesia, seiring dengan berdirinya Hizbut Tahrir berskala Internasional, organisasi ini diteruskan ke berbagai negara dipenjuru dunia termasuk Indonesia. Hizbut Tahrir masuk ke Indonesia padatahun 1982-1983, karena semangat dakwah dan dengan misi mengembalikanlslam ke dalam sistem khilafah secara International. Pada Awal 1980-an HTmenyebar gagasan khilafahnya ke berbagai kampus perguruan tinggi melaluiJaringan Lembaga dakwah kampus (Taufik, 2004). Karena pada saat itu konstelasi politikdibawah orde baru belum memungkinkan gerakan organisasi ini untukmuncul, karena terjadi ancaman intimidasi dan pembubaran dari penguasa, sehingga gerakan ini hanya melakukan aktivitas "di bawah Meja Sistem Negara".

Hizbut Tahrir dalam konteks Indonesia kemudian dikenal dengan nama Hizbut Tahrir Indonesia kemudian disingkat dengan HTI. Para Tokoh HTI banyak yang bertempat tinggal di Bogor dan upaya mereka dalam mensosialisasikan gerakannya mendapat sambutan positif dari kalangan civitas academica Institut Pertanian Bogor (IPB), sehingga salah satu pimpinan pusat HTI adalahalumnus dan dosen IPB yakni Muhammad al-Khattat (Endang, 2006). Untuk penanggungjawab kewilayahan nasional disebut Juru Bicara (Jubir) yang saatini untuk Indonesia dipegang oleh Ismail Yusanto. Sedangkan Ketua Umum Nasional dipegang oleh Hafidz Abdul Rahman (Endang, 2006).Indonesia dengan manyoritas umat Islam menjadi tujuan HTI untuk membangun politik dan mencari simpatisan untuk membangun izzah Islam dibawah naungan hilafah.

Gerakan penerapan syariat Islam tampaknya bukanlah sebuah impian yang utopis, karena di beberapa daerah sudah ada yang menerapkan syariat Islam meskipun sebahagian. Tentu kenyataan ini menumbuhkan semangat dan optimisme baru bagi kelompok-kelompok ormas dan gerakan politik Islam seperti Hizbut Tahrir yang menginginkan Islam sebagai sebuah ideologi Negara.

\section{PEMBAHASAN}

$$
\begin{aligned}
& \text { 1.1.1. Pandangan Hizbut } \\
& \text { Tahrir tentang Politik } \\
& \text { Politik adalah suatu } \\
& \text { mekanisme yang harus digunakan }
\end{aligned}
$$


Al-Fikra: Jurnal Ilmiah Keislaman, Vol. 16, No. 2, Juli - Desember, 2017 (233 268)

manusia dalam mencapai keselamatan dunia dan akhirat. Politik berusaha supaya manusia dapat bekerjasama untuk memenuhi kebutuhan pokok dan mempertahankan diri, baik terhadap ancaman yang datang dari luar maupun terhadap permusuhan yang terjadi di dalam masyarakat sendiri.

Muhammad Baqir as-Sadr berpandangan bahwa kehidupan politik adalah suatu keharusan dalam kehidupan manusia bermasyarakat. Tanpa kehidupan politik, kehidupan manusia dalam masyarakat tidak akan teratur. Tujuan bersama tidak akan dapat dicapai, jika tidak saling tolong menolog. Karena itu, menurut Ibnu Khaldun, politik adalah sebuah mekanisme yang menjadikan kehidupan manusia dalam masyarakat berjalan dengan lancar dan dapat mencapai tujuan bersama yang dicita-citakan (Ibnu, 2011)

Hampir senada dengan
pandangan tersebut, Qardhawi berpendapat bahwa Islam tidak ada artinya tanpa politik. Menurut Yusuf Qardhawi, bahwa seseorang tidak boleh berpikiran mau melepaskan Islam dari urusan politik. Jika seseorang memisahkan Islam dengan politik, maka ia telah menjadikan Islam seperti agama Budha, Nasrani dan sebagainya. Alasannya, agama non Islam hanya mengatur urusan spritual saja, dan tidak mengatur urusan politik (Yusuf, 1994).

Peranan politik dalam kehidupan kemasyarakatan manusia sangat signifikan.Sebab, menurut lbnu khaldun, kehidupan makhluk politik itu hanya dimiliki manusia saja. Binatang dan makhluk lain tidak mempunyai kehidupan seperti itu. Sebab itu, manusia menghadapi kehidupan politik itu dengan segi-segi terbaik yang dimilikinya dalam dirinya, yaitu dengan menggunakan sifatnya yang terbaik, bukan yang berburuk. (Yusuf, 1994).

Signifikansi politik direspon oleh Abdul Qadim Zallum dengan mengemukakan bahwa keterlibatan dalam aktivitas politik merupakan kewajiban setiap muslim. Dasar pijakan berpikirnya bersumber dari al-Qur'an dan as-Sunnah.

berfirman :

Di dalam al-Qur'an, Allah

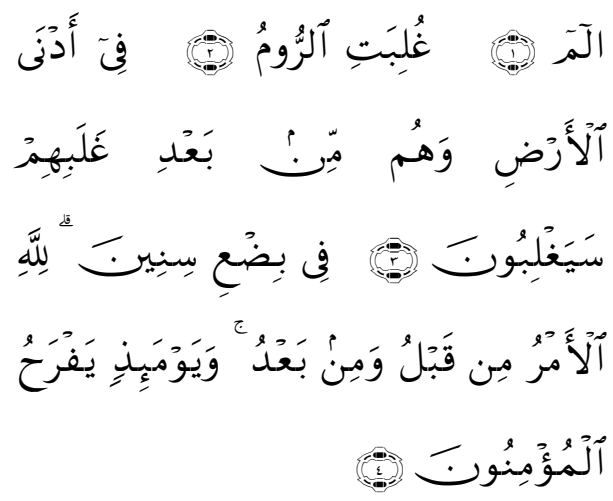

Artinya; "Alif - laam - miim.Telah dikalahkan bangsa Romawi di negeri yang terdekat. Dan mereka sesudah dikalahkan itu akan menang dalam beberapa tahun lagi. Bagi Allah-lah urusan sebelum dan sesudah mereka menang. Dan dihari itu (kemenangan bangsa Romawi) bergembiralah orang-orang yang beriman". (QS. Ar-Rum : 1-4),

Rasulullah bersabda :

Artinya; "Akan ada para amir (pemimpin), maka kalian (yang ada) mengakui perbuatannya dan (ada yang) mengingkarinya.Barang siapa yang mengakui perbuatannya (karena tidak bertentangan dengan 
Edi Sabara Manik, Hasanuddin; Strategi Membangun Kesadaran Penerapan

Syari'ah Islam Melalui Dakwah Ekstraparlementer

hukum syara', maka ia tidak diminta pertanggung jawabnya dan siapa saja yang mengingkari perbuatannya maka ia selamat. Tetapi siapa saja yang ridla (dengan perbuatannya yang bertentangan dengan hukum syara') dan mengikutinya (maka ia berdosa). Para sahabat bertanya : "apakah tidak kita perangi, ya Rasulullah?”, Rasul menjawab, "tidak selama mereka mendirikan shalat". (HR. Imam Muslim dari Ummu Salamah).

Rasulullah bersabda :

أفضـل الجهـاد كلمـة حـق عنـد سـلطان

Artinya; Jihad yang paling utama adalah mengatakan kebenaran (haq) di depan seorang penguasa yang zalim. (HR. Imam Abu Daud dari Abi Said al-Khudri).

Dari Jabir bin Abdullah, dari Rasulullah, bersabda :

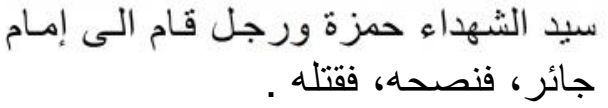

Aritinya; "Penghulu syuhada adalah Hamzah bin Abdul Muthalib dan (setara dengannya) seseorang yang berdiri dihadapan penguasa yang zalim, menyerukan (kepadanya) untuk berbuat baik dan melarangnya (berbuat kemunkaran), kemudian ia dibunuh". (HR. Imam al-Hakim). Menurut Abdul Qadim Zallum, ayat al-Qur'an dan hadishadis tersebut menunjukkan bahwa keterlibatan dalam politik merupakan kewajiban bagi kaum muslimin. Hal ini karena siyasah (politik) secara lughawi berarti memelihara urusan umat.Mengurus kaum muslimin berarti mengurusi kepentingan hidup kaum muslimin. Mengurusi kepentingan kaum muslimin berarti mengurus dan mengetahui penguasa mengatur umatnya. (Yusuf, 1994).

Abdul Qadim Zallum mengemukakan bahwa menentang kebijakan penguasa zalim merupakan bentuk aktivitas politik, dan berarti pula mengurus umat.Menyerukan kebaikan dan melarang perbuatan munkar kepada penguasa yang zalim merupakan aktivitas mengurus umat. Bersikap kritis dan berseberangan dengan penguasa, juga merupakan bentuk aktivitas mengurus umat dan kepentingan mereka. Perintah dalam hadis ini bersifat tegas, bahwa Allah menuntut kaum muslimin dengan tuntutan yang tegas untuk mengurusi umat Islam, yaitu dengan melibatkan dirinya dalam aktivitas politik. Jadi dalam hal ini, melibatkan diri dengan politik merupakan suatu kewajiban bagi kaum muslimin (Zallun, 2002).

Keterlibatan individu muslim dalam politik, menurut Abdul Qadim Zallum bertujuan melindungi kaum muslimin dari kerusakan akibat tindakan penguasa yang zalim dan musuh-musuh umat. Perintah untuk aktif dalam kehidupan politik sesuai makna hadis-hadis di atas, tidak sekedar bertujuan untuk melindungi umat dari penguasa yang zalim yang tidak mengurusi umat, tetapi juga dari kerusakan yang disebabkan oleh musuhmusuh Islam.

Menurut Abdul Qadim Zallum bahwa kewajiban kaum muslim untuk aktif dalam politik tidak terbatas politik internal (dalam negeri), yaitu mengkritisi penguasa dalam mengurus kepentingan 
umat, tetapi juga aktif dalam politik internasional (politik luar negeri), yaitu selalu mencermati rencana dan tindakan negara-negara kafir yang membahayakan umat dan berupaya menghentikannya (Zallun, 2002). Allah berfirman :

Artinya; "Alif - laam - miim.Telah dikalahkan bangsa Romawi di negeri yang terdekat. Dan mereka sesudah dikalahkan itu akan menang dalam beberapa tahun lagi. Bagi Allah-lah urusan sebelum dan sesudah mereka menang.Dan dihari itu (kemenangan bangsa Romawi) bergembiralah orangorang yang beriman". (QS. Ar-Rum: 1-4).

Dalam pandangan Abdul Qadim Zallum, kaum muslimin diwajibkan berdakwah ke seluruh penjuru dunia. Kaum muslimin tidak akan dapat melaksanakan tugas itu tanpa pemahaman terhadap politik negara-negara lain. Pemahaman terhadap politik internasional dan politik negaranegara yang akan disampaikan dakwah kepada rakyatnya dan menolak makar mereka terhadap kaum muslimin merupakan aktivitas fardlu kifayah bagi kaum mislimin. Kewajiban tersebut tidak dapat dipenuhi kecuali dengan memahami sepenuhnya politik dan hubungan internasional. Kaidah syar'i menyebutkan :

$$
\text { مالا يتم الوا جب الا به فهو وا جب . }
$$

Artinya; Sesuatu yang menyebabkan tidak sempurnanya suatu kewajiban, kecuali hanya dengan adanya sesuatu itu, maka ia (sesuatu itu) menjadi wajib.

Abdul Qadim Zallum menganalisa, bahwa memahami dan melaksanakan politik internasional merupakan fardlu kifayah atas kaum muslimin. Syara' telah membebani kaum muslimin untuk menyampaikan dakwah kepada seluruh umat manusia dan merupakan kewajiban pula untuk selalu mencermati perkembangan internasional, dengan senantiasa kritis terhadap situasi internasional, menyadari permasalahannya, mengetahui motif tiap negara dan bangsa, selalu mengikuti perkembangan politik berbagai negara, mengamati gaya politik dan hubungan internasional mereka, serta memantau setiap manuver politik yang dilakaukannya.

Menurut Taqiyuddin AnNabhani, bahwa Allah telah mewajibkan kepada kaum muslimin untuk mengoreksi penguasa. Perintah untuk melakukan koreksi ini bersifat tegas, jika penguasa merampas hak-hak rakyat, mengabaikan kewajiban-kewajiban rakyat, melalaikan urusan rakyat, menyimpang dari hukum-hukum Islam, atau memerintah dengan selain hukum yang diturunkan Allah.

Menurut Taqiyuddin AnNabhani bahwa Rasulullah Saw telah memerintahkan supaya mengingkari seorang penguasa, bahkan wajib mengingkarinya dengan berbagai sarana. Taqiyuddin An-Nabhani menambahkan, bahwa sarana yang digunakan, seperti dengan tangan, dengan senjata (pedang), tetapi dengan catatan tidak membunuh, dengan ucapan, dan dengan hati, jika tidak mampu menggunakan tangan dan ucapan, sehingga orang yang tidak mengingkarinya, dianggap ikut berdosa sama sebagaimana 
Edi Sabara Manik, Hasanuddin; Strategi Membangun Kesadaran Penerapan Syari'ah Islam Melalui Dakwah Ekstraparlementer

penguasa tersebut (An-Nabhani, 2015)

Menurut Taqiyuddin AnNabhani, dalil-dalil tentang amar ma'ruf dan nahi munkar itu merupakan dalil-dalil yang mewajibkan muhasabah (koreksi) terhadap penguasa. Dalil-dalil itu bersifat umum yang mencakup penguasa maupun yang lain. Allah telah memerintahkan amar ma'ruf dan nahi munkar tersebut dengan perintah yang tegas. Allah berfirman:

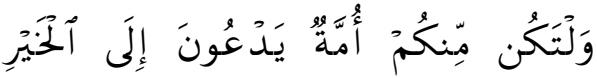

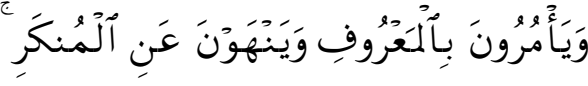

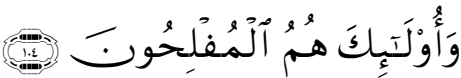

Artinya; Hendaklah ada di antara kalian, segolongan umat yang mengajak kepada kebaikan, menyuruh kepada kema'rufan dan mencegah dari kemunkaran. Mereka itulah orang-orang yang beruntung.(QS. Ali Imran : 104).

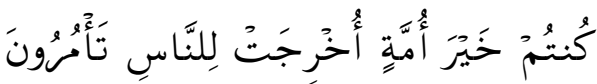

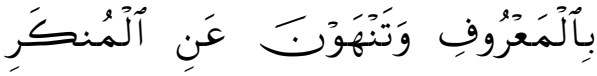

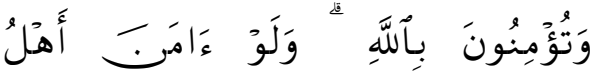

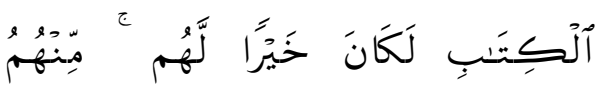

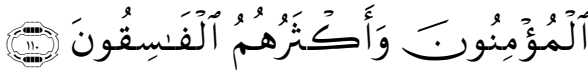

Artinya; Kalian adalah sebaik-baik umat yang dihadirkan untuk seluruh umat manusia; maka kalian (harus) menyeru kepada kema'rufan dan menolak kemunkaran dan beriman kepada Allah, Sekiranya Ahli Kitab beriman, tentulah itu lebih baik bagi mereka. Diantara mereka ada yang beriman, namun kebanyakan mereka adalah orang-orang fasik. (QS. Ali Imran : 110)

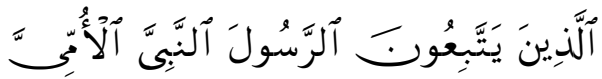

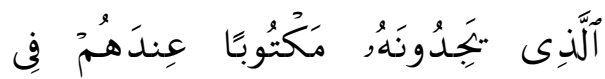

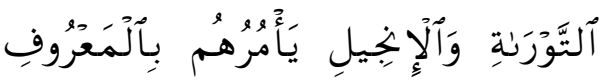

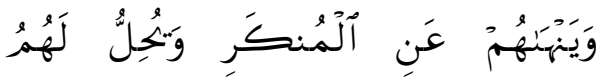

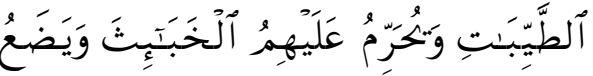

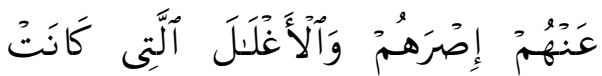

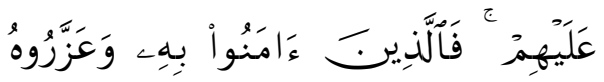

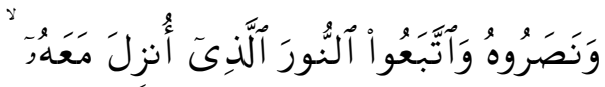

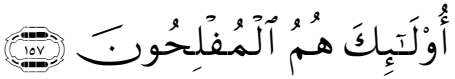

Artinya; Yaitu orang-orang yang mengikuti Rasul, Nabi yang ummi yang (namanya) mereka dapati di dalam Taurat dan Injil yang ada di sisi mereka, yang menyuruh mereka mengerjakan kema'rufan dan melarang mereka dari kemunkaran. (QS. Al-A'raf : 157).

Di dalam semua ayat
tersebut, memerintahkan amar ma'ruf dan nahi munkar. Allah menyertai perintah tersebut dengan qarinah (indikasi) yang menunjukkan adanya suatu keharusan (jazm) yaitu pujian bagi orang yang melakukannya, dengan firman-Nya:

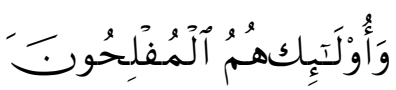


Al-Fikra: Jurnal IImiah Keislaman, Vol. 16, No. 2, Juli - Desember, 2017 (233 268)

Artinya; Mereka adalah orangorang yang beruntung. (QS. Ali Imran : 104).

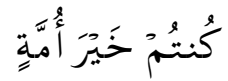

Artinya; Kalian adalah sebaik-baik umat. (QS. Ali Imran : 110).

Menurut Taqiyuddin AnNabhani, indikasi perintah itu bersifat tegas dan hukumnya adalah fardlu. Sedangkan melakukan koreksi terhadap penguasa itu tidak lain hanyalah memerintahkannya untuk berbuat ma'ruf dan mencegahnya berbuat munkar. Jadi dalam hal ini,muhasabah tersebut hukumnya fardlu.

Taqiyuddin An-Nabhani mengemukakan bahwa banyak hadis yang menjelaskan perintah pada kema'rufan dan mencegah pada kemunkaran. Rasulullah bersabda;

Artinya; Akan ada para pemimpin, lalu kalian akan mengetahui kema'rufannya dan kemunkarannya, maka siapa saja yang membencinya ia akan bebas, dan siapa saja yang mengingkarinya ia akan selamat. Tetapi siapa saja yang rela dan mengikutinya (dia akan celaka). Mereka bertanya, 'tidakkah kita akan memerangi mereka?'Rasul menjawab, 'Tidak, selama mereka masih menegakkan shalat (hukum Islam)". (HR. Muslim dari Umi Salamah)

Menurut Taqiyuddin AnNabhani hadis-hadis tersebut menunjukkan hukum wajibnya menegakkan amar ma'ruf dan nahi munkar.Sebab, hadis-hadis ini juga menunjukkan hukum wajibnya memerintah penguasa supaya melakukan kema'rufan dan mencegah dari perbuatan munkar.Jelas, bahwa maksudnya adalah mengoreksi tindakantindakan penguasa tersebut. Hanya saja, hadis-hadis tersebut menyatakan tentang penguasa secara khusus, yang berarti penguatan (ta'kid) untuk kewajiban melakukan muhasabah (AnNabhani, 2005)

Yusuf Qardhawi berpandangan, bahwa Islam mewajibkan kaum muslimin melaksanakan amar ma'ruf nahi munkar. Kewajiban ini mungkin saja dilaksanakan dalam bentuk nasehat kepada para penguasa dan kepada kaum muslimin secara umum. Menurut Yusuf Qardhawi, bahwa hal ini sejalan dengan hadis Rasulullah Agama adalah nasehat. Yusuf Qardhawi menyatakan bahwa aktivitas seorang muslim dalam menata masalah umatnya, sekarang dinamakan dengan aktivitas politik (al-Qardawi, 1994).

Pembentukan partai politik merupakan sarana yang sangat dibutuhkan untuk memperhitungkan dan menghadapi kekuasaan yang menyimpang, lalu mengenmbalikan-nya ke jalan yang benar. Yusuf Qardhawi berpendapat, bahwa hanya dengan cara inilah yang bisa berhadapan langsung dengan penguasa, memberikan nasehat kepadanya, menyuruhnya kepada yang ma'ruf dan mencegah dari yang munkar (al-Qardawi, 1994).

Abdurrahman Muhammad Khalid menyatakan, bahwa menegakkan negara (khilafah) adalah tugas yang berat dan untuk mewujudkannya sangat diperlukan keikut-sertaan seluruh kaum 
muslimin. Individu tidak akan mampu menjalankan kewajiban ini sendirian. Oleh karena itu, individuindividu seharusnya membentuk sebuah partai politik untuk berdakwah dan berjuang menegakkan negara (khilafah) sekaligus mengoreksi penguasa. Jika mereka belum membentuk partai politik tersebut, maka mereka akan berdosa, karena belum melakukan sesuatu aktivitas yang semestinya dilakukan (A. Rahman, 1992). Dalam hal ini kaidah syara' menyebutkan :

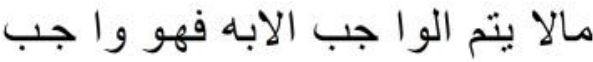

"Apabila suatu kewajiban tidak. akan terlaksana kecuali dengan adanya suatu perbuatan, maka perbuatan itu hukumnya adalah wajib".

Jika mereka membentuk suatu kelompok (organisasi) yang tidak mampu melaksanakan tujuan, yaitu mendirikan khilafah atau mengkoreksi penguasa, maka mereka juga tetap berdosa. Sebab yang diwajibkan itu bukan sekedar membentuk kelompok (organisasi) saja, tetapi membentukan gerakan dakwah yang mampu melaksanakan kewajiban tersebut, yaitu mampu menegakkan khilafah dan mengkoreksi penguasa. Dengan kata lain, yang dibentuk itu adalah suatu partai politik yang mampu melaksanakan kewajiban ini, dan bukan membentuk organisasi sosial kemasyarakatan, ikatan cendikiawan, kelompok tharikat, atau gerakan bersenjata (milisi) dan sebagainya, yang tidak mampu melaksanakan kewajiban syara' yang diperintahkan (A. Rahman, 1992).

Abdurrahman Muhammad Khalid berpendapat bahwa hukum bergabung dengan partai politik yang berusaha mendirikan khilafah dan mengoreksi penguasa adalah fardlu kifayah. Tidak ada alasan bagi individu untuk menolak bergabung dengan partai politik dengan dalih status hukumnya mubah, dengan kata lain ia bebas memilih antara bergabung dengan partai politik atau tidak. Menurut Khalid bahwa aktivitas dakwah yang bertujuan menegakkan khilafah telah diwajibkan oleh Allah atas kelompok dari kaum muslimin yang berupa organisasi politik. Mereka harus ingat kembali firman Allah :

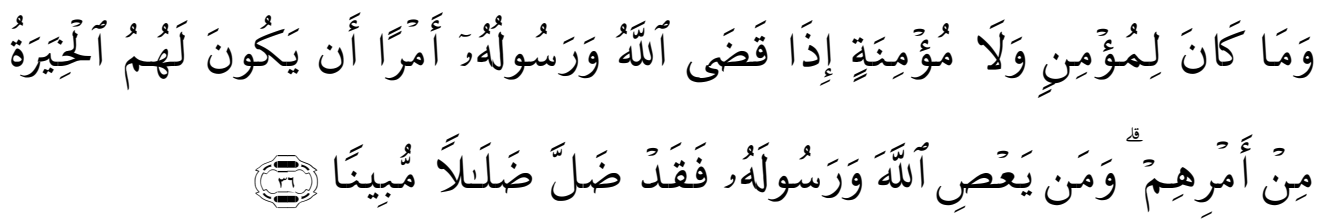

Artinya; Tidaklah patut bagi laki-laki yang mukmin dan tidak (pula) bagi perempuan yang mukmin, jika Allah dan Rasul-Nya telah menetapkan suatu ketetapan, akan ada bagi mereka pilihan (yang lain) tentang urusan mereka. (QS. Al-Ahzab : 36).
Pada dasarnya seorang muslim hendaknya melakukan apa yang diwajibkan, baik fardlu kifayah maupun fardlu 'ain, bukan selalu mencari-cari alasan untuk mengabaikan kewajibannya dalam melaksanakan fardlu kifayah. Bisa saja fardlu kifayah bisa berubah 
Al-Fikra: Jurnal Ilmiah Keislaman, Vol. 16, No. 2, Juli - Desember, 2017 (233 268)

menjadi fardlu 'ain, tetapi tidak sebaliknya (A. Rahman, 1992).

Dalam kaitan ini, Ibn Taimiyyah saat membahas amar ma'ruf nahi munkar, mengatakan, "Hukum aktivitas tersebut adalah wajib atas setiap muslim yang memiliki kemampuan, dan statusnya adalah fardlu kifayah. Namun, fardlu tersebut bisa berubah menjadi fardlu 'ain atas orang-orang yang mampu jika kewajiban tersebut belum dilaksanakan oleh yang lain".

Kewajiban mendirikan khilafah meski status awalnya adalah fardlu kifayah, namun jika kemampuan kelompok gerakan yang mengupayakannya belum cukup, maka fardlu kifayah dalam keadaan seperti ini dapat berubah menjadi fardlu 'ain, dan tetap menjadi fardlu atas setiap muslim hingga terpenuhinya kebutuhan gerakan dan kewajiban itu telah benar-benar terlaksana. Oleh karena itu, bergabung dengan partai politik yang bertujuan mendirikan khilafah hukumnya fardlu 'ain selama kekuatannya belum cukup. Setiap muslim yang melalaikan kewajiban ini akan berdosa hingga partai politik itu memiliki kemampuan yang cukup dan berhasil menegakkan khilafah.

Abdurrahman Muhammad

Khalid berargumentasi bahwa orang-orang yang tidak melibatkan diri dalam aktivitas politik yang bertujuan menegakkan khilafah dianggap berdosa. $\mathrm{Hal}$ ini disebabkan syara' telah membatasi waktu pelaksanaan kewajiban ini hanya dalam tempo tiga hari.ljma' Sahabat telah menetapkan batas waktu tersebut adalah batas waktu pengangkatan khalifah (A. Rahman, 1992). Dalam tempo tiga hari kaum muslimin wajib menyibukkan diri dalam melaksanakan kewajiban yang telah ditentukan oleh syara' atas mereka yang berada di dalam wilayah pemerintahan Islam seperti yang pernah terjadi pada pembai'atan khalifah Usman bin Affan. Boleh juga yang melaksanakan fardlu ini adalah kaum muslimin yang ada di pusat pemerintahan atau sebagian dari mereka, seperti ahlu halli wal aqdi ataupun orang-orang yang mewakili suara mayoritas kaum muslimin, seperti yang pernah terjadi pada pengangkatan khalifah Abu Bakar dan Ali bin Abi Thalib (A. Rahman, 1992).

Dalam spektrum berpikir Taqiyuddin An-Nabhani eksistensi partai politik sangat signifikan dan efektif mengoreksi penguasa sesuai yang telah diperintahkan Allah atas kaum muslimin. Esensinya merupakan tugas individu sebagai pribadi dan tugas jamaah dan partai sebagai kelompok. Allah memerintahkan mereka berdakwah kepada Islam, amar ma'ruf dan nahi munkar dan mengoreksi para penguasa.Allah memerintahkan mereka untuk mendirikan partai politik di antara mereka, yang berdiri sebagai sebuah kelompok dakwah yang menyeru kepada kebaikan atau kepada Islam, amar ma'ruf dan nahi munkar, serta mengoreksi penguasa. Allah berfirman :

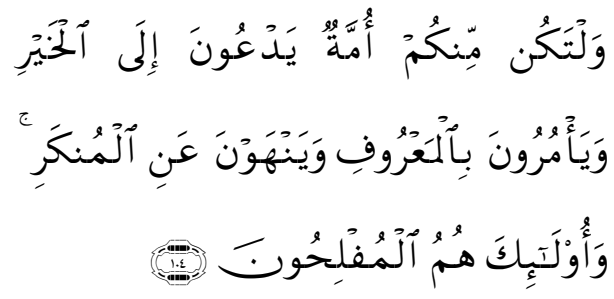


Edi Sabara Manik, Hasanuddin; Strategi Membangun Kesadaran Penerapan

Syari'ah Islam Melalui Dakwah Ekstraparlementer

Artinya; Hendaklah ada di antara kalian, segolongan umat yang mengajak kepada kebaikan, menyeru kepada kema'rufan dan mencegah dari kemunkaran, merekalah orang-orang yang beruntung.(QS. Ali Imran : 104).

Dalam perspektif Taqiyuddin An-Nabhani bahwa ayat ini berisi seruan untuk membentuk jamaah di antara kaum muslimin, yang memiliki kriteria sebagai sebuah jamaah, yang melakukan dua tugas yaitu tugas menyeru kepada Islam dan tugas mengajak pada kema'rufan serta mencegah dari kemunkaran (an nabhani, 2005)

Taqiyuddin An-Nabhani mengemukakan bahwa perintah untuk mendirikan jamaah itu merupakan perintah yang tegas.Menurutnya, bahwa perintah untuk membentuk jamaah hukumnya adalah fardlu yang harus dilaksanakan oleh seluruh kaum muslimin, sebagaimana yang telah dinyatakan di dalam banyak ayat dan hadis. Taqiyuddin AnNabhan menambahkan, bahwa perintah yang tertuang di dalam ayat tersebut bermakna wajib, yaitu fardlu kifayah bagi seluruh kaum muslimin.

Taqiyuddin An-Nabhani menganalisa, bahwa jika tugas tersebut telah terlaksana oleh sebagian orang hingga tuntas, maka yang lain telah gugur kewajibannya untuk melaksanakan tugas tersebut. Perintah ini bukan merupakan fardlu ain (berlaku untuk individu-individu muslim). Allah meminta kepada kaum muslimin agar mereka mendirikan sebuah jamaah dari kalangan mereka, yang bertugas menyeru kepada kebaikan serta amar ma'ruf dan nahi munkar. Tidak ada perintah kepada seluruh muslim untuk mendirikannya. Melainkan perintah kepada sebagian muslim yang mendirikan sebuah jamaah untuk melaksanakan kewajiban ini. Jadi, perintah di dalam ayat tersebut adalah perintah untuk mendirikan jamaah, bukan perintah untuk melakukan dua tugas tersebut. (Zallum, 2002). Kedua tugas tersebut, menurut Taqiyuddin An-Nabhani hanya merupakan penjelasan tentang tugas-tugas jamaah yang harus didirikan, sehingga tugas tersebut hanya merupakan kriteria $b$

Taqiyuddin An-Nabhani
menjelaskan bahwa sebuah jamaah yang secara langsung mampu melaksanakan tugas tersebut harus memiliki syaratsyarat tertentu, yaitu memiliki ikatan yang mengikat semua anggotanya agar menjadi satu tubuh atau sebuah kelompok. Tanpa adanya ikatan tersebut eksistensi jamaah yang melaksanakan tugas-tugas tersebut tidak akan pernah terwujud. Sedangkan syarat lain adalah adanya sesuatu yang bisa menjaga eksistensi jamaah, yaitu harus ada pemimpin yang wajib ditaati, sehingga bisa melaksanakan tugas-tugas jamaah. Menurut Taqiyuddin An-Nabhani, syara' telah memerintahkan setiap kelompok yang mencapai jumlah tiga orang atau lebih mengangkat pemimpin kelompok. Dari Abdullah bin Amr bin Ash, dari Rasulullah bersabda :

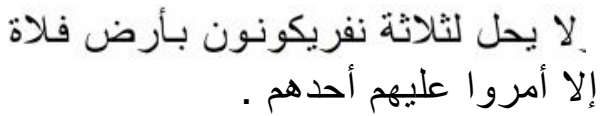

Artinya; Dan tidaklah halal bagi tiga orang yang berada di tanah lapang, 
Al-Fikra: Jurnal Ilmiah Keislaman, Vol. 16, No. 2, Juli - Desember, 2017 (233 268)

selain apabila mereka dipimpin oleh salah seorang di antara mereka. (HR. Ahmad).

Ketentuan tentang adanya ikatan antara anggota jamaah dan adanya pemimpin yang wajib ditaati, menunjukkan bahwa firman Allah "Hendaklah ada di antara kalian sekelompok umat", di atas maknanya adalah hendaknya di antara kalian ada jamaah yang memiliki ikatan yang bisa mengikat semua anggotanya serta memiliki pemimpin yang wajib ditaati. Inilah jamaah, kutlah, partai, organisasi atau apapun namanya, yang baru bisa dianggap memenuhi syarat yang menjadikannya sebagai jamaah dan mengukuhkan eksistensinya sebagai sebuah jamaah. Dari paparan tersebut, Taqiyuddin An-Nabhani berpendapat, bahwa ayat ini memerintah mendirikan partai, jamaah, organisasi, atau lembaga atau apapun yang serupa (an nabhani, 2002)

Sejalan dengan pandangan
tersebut, Ahmad Mahmud mengemukakan bahwa firman Allah dalam surah Ali Imran ayat 104 menunjukkan kewajiban dibentuk satu atau beberapa partai politik Islam dan menjelaskan pula bentuk aktivitas dan keumumannya. Pembatasan atas sejumlah perkara ma'ruf yang wajib dilaksanakan dan sejumlah kemungkaran yang harus dihilangkan bergantung pada realitas keduanya; masing-masing membutuhkan adanya penggalian syariat untuk mengubahnya (Ahmad, 2002)

Sejalan dengan pandangan tersebut, menurut Ahmad Mahmud bahwa realita sekarang umat Islam hidup tanpa adanya khilafah yang memerintah berdasarkah wahyu
Allah; umat Islam hidup di dalam negara yang tidak menerapkan hukum-hukum Allah dan tatanan kehidupan masyarakat tidaklah Islami, karena berbagai interaksi dan peraturan yang dibangunnya tidak bersumber wahyu Allah. Ahmad Mahmud mengemukakan, bahwa diperlukan adanya jamaah yang aktivitas utamanya adalah mengubah masyarakat ini menjadi masyarakat Islam dan memperjuangkan pemerintahan yang melaksanakan hukum Allah, yakni pemerintahan yang meneruskan kehidupan Islam dan mengemban dakwah ke seluruh dunia. Tujuan inilah yang harus dicapai oleh jamaah atau partai politik Islam (Ahmad, 2002).

Dalam pemikiran Taqiyuddin An-Nabhani, perintah mendirikan jamaah di dalam ayat ini yang merupakan perintah mendirikan partai politik.la menjelaskan tugas jamaah tersebut, yaitu tugas menyeru kepada kebaikan, serta amar ma'ruf dan nahi munkar. Perintah itu berarti perintah wajib untuk mengoreksi mereka. Sedangkan mengoreksi para penguasa itu merupakan kegiatan politik yang dilakukan oleh partai politik. Bahkan, kegiatan tersebut merupakan kegiatan partai politik yang paling penting. Berdasarkan paparan analitis ini, Taqiyuddin AnNabhani berpendirian bahwa ayat tersebut menunjukkan hukum wajibnya mendirikan partai politik.Sebab, partai politik tersebut bisa menyeru kepada Islam, amar ma'ruf dan nahi munkar serta mengoreksi para penguasa terhadap semua tindakan dan tingkah laku mereka.

Dengan penalarannya yang puristik, Taqiyuddin An-Nabhani 
Edi Sabara Manik, Hasanuddin; Strategi Membangun Kesadaran Penerapan

Syari'ah Islam Melalui Dakwah Ekstraparlementer

mengemukakan bahwa ayat ini menunjukkan bahwa partai-partai politik haruslah berbentuk partai yang berdiri di atas landasan aqidah Islam serta mengadopsi hukum syara tertentu. Tidak diperbolehkan partai itu berupa partai Komunis, Sosialis, Kapitalis, Nasionalis, Kesukuan, Partai menyerukan Demokrasi, Sekularisasi, Free Masonry, atau partai yang berdiri di atas landasan selain aqidah Islam serta mengadopsi selain hukum Islam. Sebab ayat tersebut telah menentukan kriteria partai-partai tersebut dengan tugas-tugas yang harus diembannya. Tugas-tugas itu adalah menyeru kepada Islam serta amar ma'ruf dan nahi munkar. Sebab itu, yang melakukan tugastugas tersebut harus mengemban dakwah Islam serta berdiri di atas landasan Islam dan mengadopsi hukum-hukum Islam (an nabhani, 1994)

Taqiyuddin An-Nabhani menganalisa, bahwa partai atau kelompok yang berlandaskan Komunisme, Sosialisme, Kapitalisme, Demokrasi, Sekularisasi, Free Masonry, Nasionalisme, Sukuisme, ataupun kedaerahan itu tidak mungkin berdiri di atas landasan Islam dan mengemban Islam serta mengadopsi hukum-hukum Islam. Melainkan dengan landasan kufur dan berkelompok dengan dasar pemikiran-pemikiran kufur. Oleh karena itu, kaum muslimin haram untuk berkelompok dengan landasan Komunisme, Sosialisme, Kapitalisme, Demokrasi, Sekularisasi, Free Masonry, Nasionalisme, Sukuisme, atau landasan-landasan lain, di luar dari Islam (al-Qardawi, 1994).
Mencermati tentang paradigma sifat partai politik, Taqiyuddin An-Nabhani menyatakan bahwa partai politik harus terbuka dan bukan partai di bawah tanah, karena partai tersebut menyeru kepada kebaikan, amar ma'ruf dan nahi munkar serta mengoreksi penguasa. Sedangkan tugas untuk meraih kekuasaan melalui tangan umat itu merupakan sesuatu yang terbuka dan terang-terangan, bukan dengan cara sembunyisembunyi dan dirahasiakan, sehingga betul-betul bisa meraih tujuan yang diharapkan.

Dalam perspektif Taqiyuddin An-Nabhani, bahwa aktivitas partai haruslah berupa aktivitas yang menyeru kepada Islam serta amar ma'ruf dan nahi munkar dengan lisan dan bukan berupa aktivitas yang bersifat fisik. Oleh karena itu, sarana-sarana yang dipergunakannya bersifat damai tidak mempergunakan senjata dan kekerasan sebagai sarana untuk melaksanakan tugasnya. Mengangkat senjata untuk menentang penguasa itu tidak diperbolehkan. Banyak hadis yang mencegah tindakan tersebut. Amar ma'ruf dan nahi munkar serta mengoreksi para penguasa itu tidak harus mempergunakan senjata, karena itu sarananya harus bersifat damai dan tidak boleh bersifat fisik (kekerasan) (alQardawi, 1994). Sedangkan mengangkat senjata untuk menentang penguasa itu hukumnya haram kecuali dalam satu keadaan, yaitu apabila nampak adanya kekufuran yang nyata. Dari Ubadah bin Shamit, dari Rasulullah, bersabda : 
Al-Fikra: Jurnal IImiah Keislaman, Vol. 16, No. 2, Juli - Desember, 2017 (233 268)

$$
\text { كفر أن لا ننـاز ع الأمـر أهلـه، الا أن تـروا }
$$

Artinya; Dan hendaklah kami tidak merampas kekuasaan dari yang berhak, kecuali (sabda Rasulullah) apabila kalian melihat kekufuran yang nyata, dimana kalian mempunyai bukti yang pasti dihadapan Allah' (HR. Muslim).

Pasca runtuhnya khilafah, banyak muncul ide pemisahan agama dan negara muncul dari para sekularis yang telah mengadopsi pemikiran yang berasal dari luar Islam.Sementara kalangan Islam puristik meyakini Islam adalah agama konprehensif yang mengatir berbagai aspek kehidupan termasuk persoalan politik (negara).

Abdul Qadim Zallum dan Taqiyuddin An-Nabhani berpendapat, bahwa Allah telah mewajibkan kepada kaum muslimin untuk mengoreksi penguasa. Perintah untuk melakukan koreksi ini bersifat tegas kepada penguasa yang zalim kepada rakyat dan menyimpang dari hukum-hukum Islam, atau memerintah dengan selain hukum yang diturunkan Allah.

Aktivitas mengoreksi tersebut lebih efektif dilakukan melalui partai politik. Abdurrahman Muhammad Khalid dan Taqiyuddin An-Nabhani memandang sangat signifikan membentuk partai politik sesuai yang telah diperintahkan Allah atas kaum muslimin. Esensinya merupakan tugas individu sebagai pribadi dan tugas jamaah dan partai sebagai kelompok. Menurut Taqiyuddin AnNabhani hukum mendirikan partai politik bermakna wajib, yaitu fardlu kifayah bagi seluruh kaum muslimin.

\subsection{Strategi Politik Hizbut Tahrir Dalam Membangun Organisasi Politik Di Indonesia}

Hizbut Tahrir (HT) atau

Liberation Party (Partai

Pembebasan) merupakan organisasi Politik Islam ideologi berskala Internasional yang aktif memperjuangkan dakwah Islam, agar umat Islam kembali kepada kehidupan Islam melalui tegaknya khilafah Islamiyyah. Hizbut Tahrir didirikan oleh Taqiyyudin alNabhani (1909-1977), (Hizbut Tahrir, 2000) yang secara resmi dipublikasikan pada tahun 1953 di Al-Quds, Yerussalem (Ihsan, 2002).Kemudian pusat gerakannya berpindah ke Yordania.

Taqiyyudin

al-Nabhani merupakan salah seorang ulama berpengaruh di Palestina, doktor lulusan Universitas Al-Azhar, Kairo, Mesir, yang sebelumnya adalah seorang hakim agung di Mahkamah Isti'naf, al-Quds, Palestina (al-Nabhani,1996) Sepeninggal Taqiyyudin al-Nabhani Hizbut Tahrir dipimpin oleh Abdul Qodim Zallum hingga wafat tahun 2003. saat ini kepemimpinan Hizbut Tahrir digantikan oleh Syeikh Atha' Abu Rastah secara Internasional (Endang, 2006)

Hizbut Tahrir telah beberapa kali berupaya pengambil alihan kekuasaan di banyak negeri-negeri Arab, seperti di Yordania pada tahun 1969, Mesir pada tahun 1973, dan serentak di Irak, Sudan, Tunisia, Al-Jazair pada tahun 1973, namun semuanya gagal.Sejak saat itulah Hizbut Tahrir mulai merubah setrategi perjuangannya dengan 
Edi Sabara Manik, Hasanuddin; Strategi Membangun Kesadaran Penerapan

Syari'ah Islam Melalui Dakwah Ekstraparlementer

lebih banyak melontarkan wacana dan membina masyarakat melalui dakwah (Ihsan, 2002).

Kegiatan dakwah banyak dilakukan oleh Hizbut Tahrir dengan mendidik dan membina masyarakat melalui training pengenalan tsaqafah (kebudayaan) Islam, memahamkan masyarakat tentang aqidah Islamiyah yang benar.Dakwah Hizbut Tahrir lebih banyak ditampakkan dalam aspek pergolakan pemikiran (ash shira' al-fikr). Hizbut Tahrir pula yang memperkenalkan istilah ghazw alfikr (perang pikiran) sebagai upaya meluruskan pemikiranpemikiran yang salah serta persepsi-persepsi yang keliru, membebaskannya dari pengaruh ide-ide barat, dan menjelaskannya sesuatu ketentuan Islam (Hizbut Tahrir, 2000) Metode yang ditempuh dalam rekrutmen dan pembinaan anggota adalah dengan mengambil thariqah (metode) dakwah Rasulullah Muhammad saw. Menurut pemikiran Hizbut Tahrir kondisi kaum muslimin saat ini hidup di darul kufur (wilayah orang-orang kafir) karena mereka menerapkan hukum-hukum kufur yang tidak diturunkan Allah SWT maka keadaan mereka serupa dengan makkah ketika Rasulullah Muhammad saw diutus untuk menyampaikan risalah Islam. Untuk itu fasi makkah dijadikan tempat berpijak dalam mengemban dakwah dan mensuritauladani Rasulullah Muhammad saw hingga berhasil mendirikan suatu daulah Islamiyah di Madinah.

Dengan mencoba pola dakwah Rasulullah Muhammad saw, Hizbut Tahrir merumuskan tiga tahapan dakwah (marhalah al- da'wah) sebagai setrategi beserta cirinya, yaitu :

Pertama, tahapan pembinaan dan pengkaderan (marhalah altatsqif), melalui halaqah-halaqah. Tahapan ini dilaksanakan untuk membentuk kader-kader yang mempercayai pemikiran dan model Hizbut Tahrir dalam rangka pembentukan kerangka tubuh partai.

Kedua, tahapan berinteraksi dengan umat (marhalah tafa'ul 'alal ummah).Tahapan ini dilaksanakan agar umat turut memikul kewajiban dakwah Islam, sehingga umat menjadikan Islam sebagai permasalahan umatnya, berjuang untuk mewujudkannya dalam realitas kehidupan.

Ketiga, tahapan pengambil alihan kekuasaan (marhalah istilam alhukm). Tahapan ini dilaksanakan untuk menerapkan Islam secara menyeluruh dan mengemban risalah Islam ke seluruh dunia (Hizbut Tahrir_b, 2000)

Hizbut Tahrir berjuang dan bergerak di tengah-tengah masyarakat dengan melontarkan wacana mendirikan kembali khilafah Islamiyah. Adapun maksud dan arti didirikannya khilafah oleh Hizbut Tahrir diantaranya adalah :

1. Penegakan hukum-hukum syari'ah ditengah-tengah kaum muslim, sekaligus pencampakan hukum-hukum kufur yang diterapkan atas mereka saat ini.

2. Penyebaran Islam ke seluruh dunia melalui dakwah dan jihad untuk mengeluarkan manusia dari kegelapan menuju cahaya yang terangbenderang.

3. Penyatuan negeri-negeri kaum muslim di dalam lindungan satu Negara di bawah kepemimpinan seorang khalifah. Tegaknya 
khalifah menandakan berakhirnya perpecahan dan ketercerai-beraian yang sengaja diadakan oleh kaum kafir dan kaki tangan mereka di negerinegeri kaum muslim.

4. Pengembalian ikatan ukhuwah islamiyah, sebagaimana sabda Nabi......"Seorang Muslim adalah saudara muslim yang lain. Karena itu, ikatan ukhuwah adalah satu-satunya ikatan yang menggantikan ikatan-ikatan Jahiliyah seperti ikatan patriotisme, nasionalisme, kesukuan dan yang lainnya, yang telah memecah belah kaum muslim saat ini.

5. Kembalinya umat mendapatkan kekuasaannya yang telah dirampas. Umat juga memegang kembali kehendak dan keputusan di tangan mereka sendiri.

6. Pembebasan negeri-negeri kaum muslim yang dikuasai oleh kekuasaan yang zolim, seperti Irak, Afganistan, Kashmir, Timor Timur dan yang lain.

7. Realisasi jaminan pemenuhan makanan pokok bagi kaum muslim dengan menempuh strategi-strategi yang bertujuan menjamin pencapaian swasembada bahkan lebih baik, baik dari hasil-pertanian, peternakan, perikanan laut maupun darat. (Ismail, 2007)

Secara garis besar, Agenda yang di emban oleh Hizbut Tahrir, yakni melanjutkan kehidupan Islam dan mengemban dakwah Islam ke seluruh penjuru dunia. Tinjauan ini berarti mengajak kaum muslim kembali hidup secara Islami dalam daulah Islam, di mana seluruh kegiatan kehidupannya oleh aturan Islam (Hizbut Tahrir 2009)
Hingga saat ini, Hizbut Tahrir memiliki pengikut puluhan juta yang tersebar luas di 40 negara dengan membentuk cabangcabang seperti di Suriah, Libanon, Kuwait, Irak, Arab Saudi, Afrika Utara, Tunisia, Sudan, Turki, Pakistan, Malaysia, Inggris, Perancis, Jerman, Australia, dan termasuk Indonesia. Meskipun di beberapa negara tidak mendapat pengakuan resmi (John, 1995).

Aktifitas Hizbut Tahrir adalah mengemban dakwah Islam untuk merubah kondisi masyarakat yang rusak menjadi masyarakat Islam, dengan merubah ide-ide yang ada menjadi ide Islam, sehingga akan menjadi opini umum ditengah tengah masyarakat, serta menjadi persepsi bagi mereka yang akan mendorongnya untuk merealisir dan menerapkannya sesuai dengan tuntutan Islam, juga dengan merubah perasaan yang dimiliki anggota masyarakat menjadi perasaan Islam, ridlo terhadap apa yang diridlai Allah, marah dan benci terhadap apa yang dimurkai dan dibenci Allah. Merubah hubungan/ interaksi yang ada di tengah-tengah masyarakat menjadi hubungan/ interaksi yang Islami, berjalan sesuai dengan hukum-hukum dan pemecahanpemecahan Islam. (Hizbut Tahrir, 2009)

Hizbut Tahrir berkeyakinan wajibnya mendirikan partai politik.untuk mendirikannya maka harus menempuh tahapan pembinaan dan pengkaderan (Marhalah at-Tastqif). Pada tahapan ini perhatian Hizbut Tahrir tidak dipusatkan kepada pembinaan tauhid dan akhlak mulia, akan tetapi Hizbut Tahrir memusatkannya kepada 
Edi Sabara Manik, Hasanuddin; Strategi Membangun Kesadaran Penerapan Syari'ah Islam Melalui Dakwah Ekstraparlementer

pembinaan kerangka Hizb (partai), memperbanyak pendukung dan pengikut, serta membina para pengikutnya dengan halaqahhalaqah dengan tsaqafah (materi pembinaan yang didalamnya sudah terdapat materi tentang tauhid dan pilar-pilar nafsiah) hizb secara intensif, hingga akhirnya membentuk partai (an nabhani 2007)

Salah satu tujuan HTI yakni mendirikanad-daulah al-Islâmiyyah dengan system khilafah adalah agar memudahkan melakukan dakwah amar makruf nahi munkar.Dakwah yang dilakukan oleh penguasaakan lebih efektif dibandingkan oleh yang tidak memiliki kekuasaan. Penguasa memiliki power dapat menyusun undang-undang atau dustur atau qanun dapat disusun berdasarkan al-Qur'an dan as-Sunnah, bahkan syariat Islam dapat dilaksanakan dalam kehidupan masyarakat. Apalagi dalam setiap hukum akan disertai dengan sangsi bagi mereka yang tidak mematuhinya. Ini merupakan kesempatan untuk dapat melaksanakan ajaran Islam secara kaffah dan mendakwahkan ke seluruh dunia. HTI mengikuti metode dakwah Rasulullah saw, karena beliaulah contoh teladan yang baik (Q.S. al-Ahzab/33: 21). HT menerapkan operasionalisasi dakwah Rasulullah saw yang dibagi dalam tiga tahap, yakni:

1. Tahap tatsqif (pembinaan dan pengkaderan). Pada tahap ini, dikenal dengan Nuqthatul Ibtida' (titik awal dakwah); dakwah dilakukan dengan mengundang orang-orang datang ke rumah, dan pada saat lain Rasulullah mendatangi orang-orang ke rumah, mengajak mereka masuk Islam, membangun keimanan dan pemahaman akan makna kalimah tahlil.

2. Tahap tafa'ul (berinteraksi) dengan umat, tahapan ini di sebut dengan Nuqthatul Intilaq (titik tolak dakwah). Tujuannya adalah agar umat melaksanakan ajaran Islam dengan baik dalam kehidupannya. Pada tahap ini ada perjuangan politik, karena berhadapan dengan pemimpin kafir quraisy yang secara sosiologis telah mapan dalam masyarakat, dan secara teologis telah memiliki keyakinan sen-diri. Dakwah dalam tahap kedua penuh dengan perjuangan, dan dinamika, karena tidak mudah merubah masyarakat yang terbelenggu oleh kekuasaan dan keyakinan tradisional untuk dirubah menjadi orang yang beriman kepada satu Tuhan, Allah SWT.

3. Tahap istilamu al-hukmi (penerimaan kekuasaan), disebut dengan Nuqthatul Irtikaz (titik sentral pusat dakwah); yakni untuk menerapkan Islam secara praktis dan menyeluruh serta mendakwahkan risalah Islamiyah ke seluruh dunia (Syabab, 2008)

Tahapan dakwah ini oleh HT juga diterapkan dalam tahapan untuk meraih kekuasaan. Namun sebelum kekuasaan dapat diraih, haruslah didirikan partai politik yang benar, yakni dengan menempuh delapan belas langkah untuk mendirikan partai ideologis dalam meraih kekuasaan. 
Al-Fikra: Jurnal IImiah Keislaman, Vol. 16, No. 2, Juli - Desember, 2017 (233 268)

Tiga tahap dakwah

Rasulullah di atas dijadikan sebagai strategi juga untuk meraih kekuasaan di Indonesia, yakni:

Marhalah pertama adalah yakni tahap pengkajian dan belajar untuk mendapatkan budaya partai.Pada tahap ini sesungguhnya tahap awal dalam pembentukan gerakan, dengan terbetuknya halqah pertama setelah memahami konsep dan metode dakwah hizb.Halqah pertama itu kemudian menghubungi anggota-anggota masyarakat untuk menawarkan konsep dan metode dakwah hizb, secara individual. Siapa saja yang menerima fikrah hizb langsung diajak mengikuti pembinaan secara intensif dalam halqah-halqah hizb sampai mereka menyatu dengan ide-ide Islamdan hukum-hukumnya yang dipilih dan ditetapkan oleh hizb, sehingga mereka memiliki kepribadian Islam, yaitu mempunyai pola pikir yang Islami (akliyah islamiyah). Juga memiliki kepribadian yang Islami (nafsiyah Islamiyah), sehingga akan menjadikan kecenderungannya selalu mengikuti Islam, dan dalam menentukan langkah-langkahnya selalu sesuai dengan ajaran Islam. Sikap yang telah terbentuk akan melahirkan sikap rela kepada sesuatu yangdiridai Allah dan Rasul-Nya, marahdan benci kepada hal-hal yang membuat Allah dan Rasul-Nya murka, lalu mereka akan tergugah mengemban dakwah ke tengah-tengah umat setelah mereka menyatu dengan Islam. Sebab pelajaran yang diterimanya dalam halqah merupakan pelajaran yang bersifat amaliyah (praktis) dan berpengaruh (terhadap lingkungan), dengan tujuan untuk diterapkan dalam kehidupandan dikembangkan di tengah-tengah umat.

Apabila seseorang telah sampai pada tingkatan ini, dialah yang akan mengharuskan dirinya bergabung dan menyatu menjadi bagian dari gerakan hizb. Demikianlah yang telah dilakukan oleh Rasulullah sawpada tahap pertama dalam dakwahnya yang berlangsung selama tiga tahun. Pada saat itu Beliau menyampaikan dakwahnya kepada masyarakat secara perorangan dengan menawarkan apa yang telah diturunkan Allah SWT kepadanya (berupa aqidahdan ideide Islam). Siapa saja yang menerimadan mengimani beliau berikut risalah yang dibawanya, maka ia akan bergabung dengan kelompok yang telah dibentuk Nabi Muhammad saw atas dasar Islam, secara rahasia. Beliau selalu menyampaikan bagian-bagian risalah, dan selalu membacakan ayat-ayat al-Qur'an yang diturunkan kepada beliau, sampai merasuk ke dalam dirimereka. Beliau menemui mereka secara sembunyi-sembunyi, mengajar mereka secara rahasia di tempattempat yang tidak diketahui masyarakat pada umumnya. Mereka melaksanakan ibadah juga secara diam-diam, sampai saatnya Islam dikenaldan menjadi pembicaraan masyarakat diMekah, sebagian mereka bahkan masuk Islam secara berangsur-angsur. Pada tahap pembentukan kader ini, hizb membatasi aktivitasnya hanya pada kegiatan pembinaan saja. Hizb lebih memusatkan perhatiannya untuk membentuk kerangka gerakan, memper banyak anggota dan pendukung, membina 
Edi Sabara Manik, Hasanuddin; Strategi Membangun Kesadaran Penerapan Syari'ah Islam Melalui Dakwah Ekstraparlementer

mereka secara berkelompok dan intensif dalam halqah-halqah hizb dengan saqafah yang telah ditentukan sehingga berhasil membentuk satu kelompok partai yang terdiri dari orang-orang yang telah menyatu dengan Islam, menerima dan mengamalkan ideide hizb,serta telah berinteraksi dengan masyarakat dan mengembangkan-nya ke seluruh lapisan umat. Setelah hizb dapat membentuk kelompok partai sebagaimana yang dimaksud di atas, juga setelah masyarakat mulai merasakan kehadirannya, mengenal ide-ide dan cita-citanya, pada saat itu sampailah hizb ke tahap kedua.

Dari penjelasan di atas jelas bahwa strategi hizbut tahri dalam membangun organisasi politiknya dengan membuka diri, menerima semua kalangan untuk menjadi kader, hizbut tahrir melakukan pendekatan mulai dari teknokrat, mahasiswa, akademisi, ulama dan bahkan mereka juga melakukan pandekatan kepengusahapengusaha yang bisa menerima ide-ide politik mereka. Hizbut tahri dalam melakukan pembinaan terhadap kader-kadernya melalui halaqah-halaqah.

Orientasi gerakan organisasi Islam di Indonesia sangat beragam sesuai dengan corak pemikiran para pendiriatau penggeraknya dalam memahamiajaran Islam, sehingga dapat dipilah menjadi tiga orientasi gerakan, yakni:

1. Orientasi murni dakwah amar makrufnahi munkar. Artinya, gerakan inihanya berorientasi dakwah saja, tidaktertarik ke politik praktis. Orientasi inisungguh mulia, karena membangun masyarakat ke arah yang lebih baik dengan melalui perbaikan, perubahan, dan melakukan transformasi sesuai kondisi obyektif masyarakat yang menerima dakwah. Kondisi kemiskinan harta benda, ilmu, etika dan kemiskinan orientasi masa depan, dari waktu kewaktu tidak berkurang melainkan terus bertambah. Dalam teori sosiologi pembangunan disebut pembangunan daribawah yakni membangun rakyat menjadi manusia seutuhnya, lahir batin,dunia akhirat.

Gerakan Islam yang berorientas dakwah tidak memiliki kesamaandalam strategi dan metode berdakwah.Ada yang menggunakan metode kekerasan, ada yang dengan lemah lembutdari rumah ke rumah, ada yang dengankebijakan, memberikan nasehat yang baik dan melakukan dialog keagamaan.

2. Orientasi murni politik. Artinya gerakanini mengambil jalur politik struktural,melalui politik kekuasaan, dengan mendirikan partai politik yang bercirikan Islam, dan gerakan politik nonparlemen.

Gerakan Islam yang berada dalamorientasi ini hanya dengan politiklslam dapat ditegakkan, karena kalaugerakan Islam telah berkuasa dalam suatu negara, maka dengan mudah mengubah tatanan politik, ekonomi, sosial budaya, pertahanan keamanan, dan pendidikan sesuai dengan ajaran Islam. Din wa dauah 
(agama dan negara) menjadi satu kesatuan integral, tidak dapat dipisahkan.

Namun sayangnya, hampir semua gerakan Islam di dunia yang berorientasi politik yang kemudian disebut gerakan politik Islam, tidak selalu menang dalam perebutan kekuasaan melalui prosedur pemilihan umum. Gerakan Politik Islamdi beberapa negara, misalnya di negaranegara Asia Tenggara (Thailand, Philipina, Vietnam, Malaysia, dan Burma) tidak pernah memegang kekuasaan. Ini suatu problem serius bagi gerakan politik Islam, walaupun jumlah umat Islam tergolong besar, sehingga tidak ada hubungan signifikan antara jumlah umat Islam dengan perolehan suara partai politik Islam.

3. Memiliki orientasi dakwah dan politik. Inilah yang disebut dua sayap, yakni sayap dakwah dan sayap politik. Ini dapat dimaknai bahwa dakwah untuk kepentingan politik, dan politik dijadikan payung untuk berdakwah. Makna yang pertama bahwa semua aktivitas dakwahnya memiliki kepentingan politik yang pada akhirnya dijadikan pijakan untuk meraih kekuasaan, bahkan keluhuran nilai-nilai zakat, infak, sadaqah yang dibagikan kepada mereka yang berhak menerima, mengandung kepentingan politik. Untuk itulah sering dijumpai dalam acara bakti sosial kedaerah-daerah bencana, ke desa-desa dan ke komunitas orang-orang lemah, bendera-bendera dan identitas partai politik selalu mendomininasi, lucunya besarnya nominal dari anggaran baktisosial lebih kecil dibandingkan dengan besarnya belanja untuk bendera danatribut lainnya. Makna yang kedua, politik dijadikan payung untuk berdakwah, artinya kalau kekuasaan telah berada dalam genggamannya, maka dijadikan sebagai alat untuk berdakwah melalui jalur instruksi dan pembuatan undang-undang, peraturan daerah, surat keputusan yang memaksa orang untuk berislam dengan baik.

Orientasi dua sayap ini memang memiliki nilai positif dan negatifnya. Nilai positifnya sebagai bentuk perwujudan dari kesempurnaan Islam, yang mengatur kehidupan manusia secara menyeluruh, termasuk kehidupan berbangsa dan bernegara. Dakwah dan politik tidak dapat dipisahkan, karena dalam dakwah juga perlu strategi, metode dan kekuasaan. Nilai negatifnya, dua sayap tersebut dapat mereduksi nilai luhur agama Islam itu sendiri, seolah-olah orientasinya hanya kekuasaan belaka, apalagi sering ditempuh berbagai macam cara untuk sekedar meraih kekuasaan, termasuk membeli suara secaralangsung.

Sejak awal Hizbut Tahrir maupun HTI memang di desain sebagai organisasi politik.Tetapi berbeda dengan organisasi politik yang dikenal selama ini.HTI tidak mendaftarkan diri secara formal sebagai parpol yang ikut dalam pemilu. HTI menerjemahkan pertai 
Edi Sabara Manik, Hasanuddin; Strategi Membangun Kesadaran Penerapan

Syari'ah Islam Melalui Dakwah Ekstraparlementer

politik dalam pengertian yang luas, yaitu sebagai suatu organisasi yang aktifitasnya bertujuan mengoreksi kekuasaan dan membangunnya secara benar. Hal ini dilakukan karena menurut HTI dalam situasi sekarang ini banyak partai Islam justru membingungkan umat Islam sendiri.Oleh karena itu, HTI tidak mengikuti jejak partaipartai lain yang berdasarkan Islam untuk ikut andil dalam pemilu yang kemudian dapat menjadi anggota legislatif. Namun tidak menutup kemungkinan pada saatnya nanti HTI akan berubah menjadi partai politik, sebagaimana yang dilakukan oleh Hizbut Tahrir Yordania, Libanon, dan lain sebagainya, karena secara tekstual dan kontekstual HT sangat mencita-citakan pembebasan, yakni membebaskan negeranegera kaum muslimin dari cengkraman "Penguasa Zolim atau Penjajah". Tentunya hal tersebut bisa terwujud manakala HTI masuk dalam sistem parlemen.Namun untuk menjadi partai politik peserta pemilu memerlukan waktu yang tepat.

Sebagai bagian dari Hizbut Tahrir, HTI juga sangat menekan kanpentingnya peran negara (dawlah) atau kekhilafahan sebagai sarana penerapan syari'ah Islam. Syari'ah dalam pandangan kelompok ini harus ditopang oleh kekuatan negara.Oleh karena itu, kelompok ini mengusung ide perlunya mendirikan kembali khilafah Islamiyah atau kekhilafahan Islam. Sementara kekhilafahan dalam Islam sendiri berakhir sejak tahun 1924.

Hal ini bisa ditemukan dalam pemerintahan negara Madina, di mana Muhammad membangun sistem pemerintahan dengan sistem teokrasi, karena nabi memang memerintah atas nama Tuhan, yang dilengkapi dengan syari'at-Nya yang diwahyukan kepadanya, baik dalam bentuk alQur'an maupun al-Hadits.

Dalam praktek kekuasaannya baik dalam hal eksekutif, legislatif maupun yudikatif berada di tangan nabi sendiri, meskipun kadangkadang beliau juga mendelegasikan kepada salah seorang sahabatnya. Sebagai seorang nabi yang memiliki sifat ma'shum (terjaga dari perbuatan maksiat), semua tindakan dan ucapan yang beliau lakukan selalu dikontrol Allah, sehingga loyalitas kaum muslimin kepada beliau pun bersifat absolut. Meskipun demikian, dalam memecahkan persoalan-persoalan yang muncul nabi juga sering melakukan musyawarah dengan melibatkan partisipasi para sahabatnya, dan tidak jarang beliau memutuskan secara demokrasi (suara terbanyak) dan menerima usulanusulan dari sahabatnya (Zainul, 2005).

Sesungguhnya pemahaman dan penafsiran terhadap konsep Islam dalam kaitanya dengan politik terdapat tiga golongan. Golongan pertama menyatakan bahwa dalam Islam terdapat Sistem politik dan pemerintahan, karena Islam adalah agama yang pari purna.Golongan kedua menyatakan dalam Islam tidak ada system politik dan pemerintahan, namun mengandung ajaran-ajaran dasar tentang kehidupan bermasyarakat dan bernegara. Sedangkan golongan ketiga berpendapat Islam sama sekali tidak terkait dengan politik dan 
Al-Fikra: Jurnal Ilmiah Keislaman, Vol. 16, No. 2, Juli - Desember, 2017 (233 268)

pemerintahan, dan ajaran agama hanya berkisar tentang tauhid, ritual pembinaan akhlak dan moral manusia (Munawir, 1993)

Din Syamsuddin mengemukakan bahwa berbeda tentang hubungan agama dan negara. Pertama, hubungan integralistik, yaitu agama dan negara tidak dapat dipisahkan. Wilayah agama juga meliputi politik. Dengan kata lain negara merupakan lembaga politik dan sekaligus lembaga keagamaan. Penyelenggara pemerintahan atas dasar kedaulatan Tuhan, karena memang kedaulatan itu berada di tangan Tuhan. Artinya bahwa agama dijadikan sebagai landasan dalam kehidupan berbangsa dan bernegara. Aturan-aturan atau hukum-hukum yang diberlakukan adalah hukum agama, yang dalam hal ini adalah hukum syari'at Islam. Paradigma ini dianut oleh kelompok syi'ah,dan juga kelompok-kelompok revivalism Islam.

Kedua, Simbiosistik, yaitu hubungan timbal balik dan saling memerlukan. Agama memerlukan negara, karena dengan agama negara dapat berkembang dalam bimbingan dan etika moral. Paradigma ini dipakai oleh kebanyakan pemikir politik Islam abad pertengahan seperti alMawardi, al-Ghazali dan Ibn Taimiyah.

Ketiga,

Paradigma sekularistik. Paradigma ini menolak baik hubungan integralistik maupun simbioistik antara agama dan negara. Bahkan mengajukan gagasan pemisahan agama dan negara secara ketat, dan menolak pendasaran negara kepada Islam.Agama tidak mengurusi negara dan negara tidak mengurusi agama. Keduanya tidak ada hubungan sama sekali, karena agama itu mengatur hubungan dengan tuhan, sementara negara mengatur hubungan dalam kehidupan bermasyarakat. Maka keduanya tidak boleh saling mengintervensi, karena wilayahnya sudah berbeda. Maka dalam penyelenggaraan negara seolaholah tidak berhadapan dengan pemeluk agama dan menganggap agama tidak ada dalam masyarakat dalam suatu negara itu.Salah seorang pemrakarsanya adalah Ali Abd al-Raziq. Di perjelas pula bahwa Islam tidak mempunyai kaitan apapun dengan sistem pemerintahan dan kekhalifahan, termasuk al-khulafa al-rasyidun bukanlah sebuah sistem politik keagamaan atau keislaman tetapi system duniawi (M. Din, 2002).

Aktifitas Hizbut Tahrir adalah mengemban dakwah Islam untuk merubah kondisi masyarakat yang rusak menjadi masyarakat Islam, dengan merubah ide-ide yang ada menjadi ide Islam, sehingga akan menjadi opini umum ditengahtengah masyarakat, serta menjadi persepsi bagi mereka yang akan mendorongnya untuk merealisir dan menerapkannya sesuai dengan tuntutan Islam, juga dengan merubah perasaan yang dimiliki anggota masyarakat menjadi perasaan Islam, ridlo terhadap apa yang diridlai Allah, marah dan benci terhadap apa yang dimurkai dan dibenci Allah. Merubah hubungan/interaksi yang ada di tengah-tengah masyarakat menjadi hubungan/interaksi yang Islami, berjalan sesuai dengan hukum-hukum dan pemecahan- 
Edi Sabara Manik, Hasanuddin; Strategi Membangun Kesadaran Penerapan

Syari'ah Islam Melalui Dakwah Ekstraparlementer

pemecahan Islam (Hizbut Tahrir, 2009).

Seluruh aktifitas yang dilakukan Hizbut Tahrir bersifat politik, di manaHizbut Tahrir memperhatikan urusan masyarakat sesuai dengan hukum dan pemecahan yang syar'i.Sebab politik adalah mengatur dan memelihara urusan masyarakat sesuai dengan hukum dan pemecahan Islam (Hizbut Tahrir, 2009).

Perjuangan politik Hizbut Tahrir Indonesia ini juga tampak jelas dalam menentang para penguasa, mengungkapkan penghianatan dan persekongkolan mereka terhadap umat, melancarkan kritik, kontrol dan koreksi terhadap mereka, serta berusaha menggantinya apabila hak-hak umat dilanggar atau tidak menjalankan kewajibannya terhadap umat, atau jika mereka melalaikan salah satu urusan umat, atau mereka menyalahi hukumhukum Islam (Hizbut Tahrir, 2009). Hal ini dilakukan HTI diluar perkara pemerintahan ataupun yang menyangkut pemerintahan.

Disisi lain aktifitas HTI tidak bersifat akademik. HTI bukanlah sekolahan. Seruannya bukan berbentuk nasehat-nasehat dan petunjuk-petunjuk (yang menjemukan dan kering). Aktifitasnya bersifat politik, dengan cara mengungkapkan fikrah-fikrah (ide) Islam beserta hukum-hukumnya, untuk dilaksan akan, diemban dan diwujudkan dalam kenyataan hidup bermasyarakat dan bernegara. Karena dengan dakwah dan penerapan hukum Islam inilah dapat menjawab dan memecahkan problematika manusia secara keseluruhan, baik dibidang politik, ekonomi, pendidikan, sosial kemasyarakatan, dan lain-lain (Hizbut Tahrir, 2009)

Perjuangan harus terus berlanjut, tidak boleh berhenti, meskipun berbagaitan tangan dan tekanan menghadang.Demikian prinsip penting Hizbut Tahrir Indonesia (HTI) dalam melakukan segala aktifitas. Perjuangan politik ini secaragaris besar mencakup pembinaan intensif untuk mencetak kader-kader dakwah, membina umat dalam tsaqafah Islam, serta mengoreksi penguasa yang berseberangan dengan Islam dan merugikan umat, misalnya dengan mendatangi parlemen dan penguasa untuk mengkritisi kebijakan politik mereka. HTI juga selalu berusaha membongkar kebiadaban penjajah seperti Amerika Serikat (AS) dan negaranegara sekutunya yang selama ini mencengkeram umat Islam, termasuk kerjasama mereka dengan para penguasa di negerinegeri Islam.Dengan aktifitas ini akan muncul kader-kader dakwah yang siap terjununtuk berdakwah sehingga terbentuk kesadaran umat untuk kembali kepada khilafah. Hal ini semakin diperkuat dengan dukungan al-Quwwah (elite politik strategis), sehingga untuk pertama kalinya secara terbuka Hizbut Tahrir mengampanyekan tentang kewajiban khilafah Islamiyah dalam konferensi International Khilafah Islamiyyah. Dalam melakukan segala aktivitas operasional politik, HTI merujuk Surat Ali 'Imron ayat 104 yang Artinya : "Hendaklah ada diantara kamu umat yang menyeru kepada kebaikan, menyuruh dengan ma'ruf (yang baik-baik) dan melarang dari yang mungkar, dan mereka itulah 
Al-Fikra: Jurnal IImiah Keislaman, Vol. 16, No. 2, Juli - Desember, 2017 (233 268)

yang menang". (Q.S. Ali Imron: 104)

$\mathrm{HTI}$ berkeyakinan wajibnya mendirikan partai politik.untuk mendirikannya maka harus menempuh tahapan pembinaan dan pengkaderan (Marhalah atTastqif). Pada tahapan ini perhatian HTI tidak dipusatkan kepada pembinaan tauhid dan akhlak mulia, akan tetapi HTI memusatkannya akan tetapi HTI memusatkannya kepada pembinaan kerangka Hizb (partai), memperbanyak pendukung dan pengikut, serta membina para pengikutnya dengan halaqahhalaqah dengan tsaqafah (materi pembinaan) hizb secara intensif, hingga akhirnya membentuk partai (an nabhani, 2007).

Setelah berdirinya partai politik dan berhasil dalam tahapan pembinaan dan pengkaderan, kemudian yang dilakukan selanjutnya adalah berinteraksi dengan umat (Tafa'ul ma'al Ummah).Tahapan ini penting untuk keberhasilan partai dalam mencapai tujuan. Karena sekalipun anggota partai banyak jumlahnya dalam masyarakat, tetapi jika tidak berinteraksi dengan umat, mereka tetap tidak akan mampu mengemban tugas sendiri sekalipun mereka kuat.

Disamping sejumlah aktivitas diatas, sebagai partai politik Ideologis, HTI terus melakukan upaya pembinaan terhadap anggotanya berupa halaqahhalaqah dengan buku-buku yang sistematis dan di mutabanat. Penuturan DPD I Riau Ardiansyah Shahab, disamping menyuarakan aspirasi masyarakat, HTI juga bergerak bersama umat dengan mengisi berbagai macam kegiatan keumatan, seperti mengisi khutbah jum'at, ceramah ramadhan, ceramah hari besar Islam, dan kultum sebagai bagian dari pembinaan umum. Upaya rekrutmen juga dilakukan secara terus menerus melalui sejumlah dawrah dirasah dan trainingtraining ke Islaman.Semua itu merupakan bagian dari aktivitas politik dan dakwah HTI untuk membangun kesadaran umat dalam menegakkan syari'at dan khilafah Islamiyyah.

Adapun kitab-kitab yang dikaji oleh anggota hizbut tahrir adalah sebagai berikut:

1. Nidzam al-Islam; (peraturan hidup dalam Islam)

2. At-Takattul al-Hizbi; (pembentukan partai politik)

3. Mafahim Hizb at-Tahrir; (pokok-pokok pemahaman Hizbut Tahrir)

4. Min Muqawwimat an-Nafsiyyah al-Islamiyyah (Pilar-Pilar Nafsiyah Islamiyah)

5. Ad-Daulah al-Islamiyyah; (Daulah Islam)

6. Ajhizah Daulah al-Khilafah. (Struktur Negara Khilafah)

7. An-Nidzam al-Ijtima'l Islam; (Sistem Pergaulan dalam Islam)

8. An-Nidzam al-lqtishadi fil Islam; (Sistem ekonomi Islam)

9. Al-Amwal fi Daulah al-Khilafah; (sistem keuangan Negara Khilafah)

10. Mafahim as-Siyasah li Hizb atTahrir; (Pokok-pokok pemikiran Politik Hizbut Tahrir)

11. As-Syakshiyyah al-Islamiyyah I, II dan III. (Kepribadian Islam Jilid I, II dan III)

12. Kitab Nizhâm al-H ukm fî alIslâm (Sistem Pemerintahan Islam). 
Edi Sabara Manik, Hasanuddin; Strategi Membangun Kesadaran Penerapan

Syari'ah Islam Melalui Dakwah Ekstraparlementer

13. Kitab Nadharât Siyâsiyah li Hizbut Tahrir (Beberapa Pandangan Politik menurut Hizbut Tahrir).

14. Kitab Muqaddimah ad-Dustûr (Pengantar Undang-undang Negara Islam)

15. Kitab Al-Khilâfah (Khilafah).

16. Kitab Kayfa Hudimat alKhilâfah (Dekonstruksi Khilafah: Skenario di Balik Runtuhnya Khilafah Islam).

17. Kitab Nizhâm al-'Uqûbât (Sistem Peradilan Islam).

18. Kitab Ahkâm al-Bayyinât (Hukum-hukum Pembuktian dalam Pengadilan)

19. Kitab Naqd al-Isytirâkiyyah alMarksiyah (Kritik atas Sosialisme-Marxis).

20. Kitab At-Tafkîr (Nalar Islam: Membangun Daya Pikir).

21. Kitab Sur'ah al-Badîhah (Mempercepat Proses Berpikir).

22. Kitab Al-Fikr al-Islâmî (Bunga Rampai Pemikiran Islam).

23. Kitab Naqd an-Nadhariyah alIltizâmi fî Qawânîn alGharbiyyah (Kritik atas Teori Stipulasi dalam Undangundang Barat).

24. Kitab Nidâ' Hâr (Panggilan Hangat dari Hizbut Tahrir untuk Umat Islam).

25. Kitab As-Siyâsah allqtishâdhiyyah al-Mutsla (Politik-Ekonomi Islam). Di samping itu, terdapat ribuan selebaran-selebaran, bukletbuklet, dan diktat-diktat (surat-surat terbuka kepada para penguasa dan pemimpin gerakan politik) yang dikeluarkan oleh Hizbut Tahrir sejak berdirinya sampai sekarang.
5.2. Strategi politik Hizbut Tahrir dalam membangun kesadaran politik masyarakat Indonesia
Strategi hizbut tahrir

Indonesia dalam membangun kesadaran politik masyarakat dengan perlawanan terhadap Kapitalisme, Neo Liberalisme, Demokrasi, dan Amerika, karena semua ideologi ini menjadi sumber kerusakan di Indonesia kususnya dan dunia pada umumya;

Khilafah yang menjaga Islam, menjaga tanah air, menjaga nyawa, kehormatan dan harta benda rakyat, baik Muslim maupun nonMuslim. Hizbut Tahrir yang terus berjuang untuk menegakkan kembali Khilafah Rasyidah. Mengingat ini merupakan kewajiban agung yang diwajibkan oleh Allah kepada kalian.Dan Allah melarang kalian berhukum kepada selain hukum Allah, di antara sistem-sistem kufur yang tidak berasal dari Allah. Syariah yang yakini akan bisa diterapkan dalam semua urusan kehidupan, dan hanya dalam Khilafah saja legislasi syariah bisa diwujudkan. Khilafah, dan berusaha sungguh-sungguh untuk menegakkannya. Khilafah adalah benteng pelindung. Khilafah adalah tempat berseminya kemuliaan dan kebanggaan. Dengan Khilafah kehormatan kami akan terlindungi, kami akan bersatu, suara kami akan sama, dan kekayaan kami akan terpelihara.

Sistemlslam yang diterapkan oleh daulahlslam atau Khilafahlslam berbeda dengan sistemkapitalisme. Penerapan Islam oleh sistem pemerintahan Khilafah mewujudkan tidak hanya kesejahteraan rakyat, namun juga 
Al-Fikra: Jurnal IImiah Keislaman, Vol. 16, No. 2, Juli - Desember, 2017 (233 268)

ketenteraman hidup seluruh warganya, termasuk di dalamnya kaum perempuan. Khilafah mengangkat perempuan dalam posisi terhormat dan mulia.Khilafah memastikan mereka mampu menjalankan peran mereka untuk melahirkan dan mencetak generasi.

Khilafah Islam melaksanakan tanggung-jawabnya dalam rangka menjaga kehormatan perempuan. Khilafahakan menerapkan syariah Islam yang dengan sangat tegas menjaga kehormatan perempuan. Aturan tersebut di antaranya adalah keharusan meminta izin ketika memasuki kehidupan khusus orang lain. Ini dimaksudkan agar perempuanyang di dalamnya dibolehkan melepas jilbabtidak terlihat auratnya oleh laki-laki yang bukan mahram-nya.

Islam pun mewajibkan perempuan untuk menutupi seluruh tubuhnya (kecuali wajah dan dua telapak tangannya) serta mengenakan kerudung dan jilbab ketika keluar rumah. Khilafahlslam juga akan memerintahkan mahramnya untuk menemani perempuan ketika ia bepergian jauh. Khilafahakan melarang perempuan untuk bepergian sejauh perjalanan lebih dari sehari semalam seorang diri tanpa ditemani mahram-nya.

Khilafahakan menguasai media massa sehingga konten yang disampaikan tidak menyimpang dari syariahlslam. Media massa bagi Khilafah dan kepentingan dakwah Islam mempunyai fungsi strategis. Di dalam negeri, media massa berfungsi untuk membangun masyarakat Islami yang kokoh. Karena itu Khilafah akan mengawasi media-media swasta yang ada, baik cetak maupun elektronik agar tidak membahayakan masyarakat. Untuk menjaga kehormatan perempuan dan keluarga muslim, Khilafah akan meniadakan sama sekali tayangan-tayangan yang mengumbar aurat, pornografipornoaksi ataupun bersifat kekerasan. Pasalnya, tayangantayangan tersebut akan menumbuhsuburkan kemaksiatan di tengah-tengah masyarakat yang berakibat pada pelanggaran kehormatan perempuan.

Dalam membangun kesadaran politik masyarakat Indonesia HTI mesti masuk kedalam system dengan mengikuti pemilu atau berafiliasi dengan salah satu partai Islam, karena untuk membangun kesadaran masyarakat mesti melalui pendidikan dan partisipatif, HTI selama ini tidak partisipatif dalam pemilihan umum, secara pendidikan HTI melakukan pembinaan terhadap kaderkadernya melalui halaqah-halaqah untuk melakukan pencerahan bagi masyarakat.

\begin{tabular}{llr}
\multicolumn{1}{c}{ Strategi } & \multicolumn{1}{c}{ politik yang } \\
diusahakan oleh HTI untuk & HTI \\
membangun & opini khilafah al- \\
Islamiyyah adalah dengan
\end{tabular} demonstrasi, sebagai media untuk membentuk opini publik, dengan tujuan mempengaruhi kebijakan pemerintah, atau memberikan masukan kepada pemerintah dalam membuat kebijakan politik, ekonomi,dan kebijakan yang menyangkut hiduporang banyak. Demonstrasi selain sebagai media untuk memobilisasi massa dalam merespon setiap persoalan keummatan dan kebangsaan, juga menjadi salah satu carayang 
Edi Sabara Manik, Hasanuddin; Strategi Membangun Kesadaran Penerapan

Syari'ah Islam Melalui Dakwah Ekstraparlementer

mudah untuk mempengaruhi massadan menciptakan nalar publik sesuai dengan yang diperjuangkan. Selain itu demonstrasi dengan mengerahkan massa dalam rangka menunjukkan eksistensinya sebagai gerakan yang sigap, cepat, dan tanggap atas problema yang sedang dihadapi oleh umat dan bangsa.

$\mathrm{HTI}$ dikenal sebagai parpol yang tidak ikut dalam perebutan kursi di parlemen atau di pemerintahan. Aksi demonstrasi yang dilakukan oleh HTI memunculkan kesadaran politik dan semangat perjuangan. Artinya bahwa ketika demo itu semakin hari semakin besar, maka akan memunculkan kekuatan masa yang masif, yang diperkirakan cepat atau lambat orang tidak bisa mengabaikan begitu saja, karena ekspresi dari aspirasi masyarakat itu, diantaranya dalam konteks kehidupan sekarang ini tercermin dari seberapa besar masyarakat itu terlibat di dalam demonstrasi, semakin besar jumlah umat yang mengikuti demonstrasi, menunjukkan semakin berarti besar pula aspirasi masyarakat.

Dakwah yang dikemas oleh HTI adalah dakwah politik, maka semua buku Taqiyuddin anNabhani sebagai rujukan materi dakwah, baik melalui majalah, tabloid, bulletin, pengajian umum, khutbah jum'ah, radio, live streaming, kajian-kajian halqah, diskusi, seminar dan berbagai macam pelatihan.

Strategi dakwahnya melalui cultural dan struktural atau politik, inilah yang membedakan dengan strategi dakwah organsasi massa Islam lainnya. Hanya saja, strategi politik masih berkisar pembentukan opini publik melalui demonstrasi pengerahan massa, belum berani tampil menjadi partai politik ideologis yang resmi diakuioleh pemerintah. Aspirasi politik HTI masih menyebar ke semua partai politik, karena tidak ada instruksi dari DPP HTI untuk menyalurkan ke salah satu partai politik peserta pemilihan umum.

\subsection{Kesimpulan}

Berdasarkan pembahasan di atas dapat disimpukan bahwa;

1. Strategi hizbut tahrir dalam membangun politiknya dengan membuka diri, menerima semua kalangan untuk menjadi kader, hizbut tahrir melakukan pendekatan mulai dari teknokrat, mahasiswa, akademisi, ulama dan mereka juga melakukan pandekatan kepengusaha-pengusaha yang bisa menerima ide-ide politik mereka. Hizbut tahrir dalam melakukan pembinaan terhadap kader-kadernya melalui halaqah-halaqah dan Daurah-daurah yang bertujuan untuk membentuk anggota dan kader hizbut tahrir yang memiliki kepribadian Islam (Syakhsiyah Islamiah; akliah islamiah dan nafsiah islamiah).

2. Strategi dakwahnya melalui cultural dan struktural atau politik, inilah yang membedakan dengan strategi dakwah organisasi massa Islam lainnya. Namun peneliti memahami strategi yang dilakukan oleh hizbut tahrir lebih banyak ditekankan kepada pendekatan cultural. Disamping itu, strategi politik yang dilakukannya bersifat ekstra parlementer. Misalnya 
Al-Fikra: Jurnal IImiah Keislaman, Vol. 16, No. 2, Juli - Desember, 2017 (233 268)

\begin{abstract}
pembentukan opini publik melalui demonstrasi pengerahan massa, konferensi, kunjungan kelembaga-lembaga

pemerintahan, mukhtamar, seminar-seminar, daurahdaurah dan halaqah-halaqah. Hizbut tahrir memiliki karakteristik dakwah yang berbeda dengan gerakan Islam lainya; Yakni Fikriyan (Pemikiran), Siyasiyan (bersifat Politik), dan Lamadiyah (tanpa kekerasan) strategi inilah yang membuat Hizbut tahrir aman dari tindakan refresif pemerintah Indonesia; karena sistem perundang-undangan yang berlaku di negeri ini menjamin kebebasan warga negaranya untuk berserikat dan berpendapat bahkan untuk mewujudkan tujuan gerakannya selagi itu dicapai tanpa menggunakan kekerasan.
\end{abstract}

\section{DAFTAR PUSATAKA}

The emerginga peran LSM dalam hubngan internasional.Akses dari

http://nccur.lib.nccu.edu.tw/bit stream $/ 140.119 / 33686 / 8 / 5300$ 3108.pdf.pada tanggal 25 Februari 2012.

The New Interntional Webster's Comprehensive Dictionary of the english language: Encyclopedic Edition, hal 1091.

Nasrah/selebaran Hizbut Tahrir Chapter Kampus Pekanbaru, Refleksi 2012: Kapitalisme Sumber Bencana, Khilafah Solusinya, 31 desember 2012. (Nasrah tersebut penulis terima di hari dilaksanakannya Aksi,31 des 2012) yang dikeluarkan secara resmi oleh HizbutTahrir Chapter Kampus kota Pekanbaru.

Ahmad Mahmud, Ad-Dakwah Ila alIslam, terj. Mahbubah (Bogor: Pustaka Thariqul Izzah, 2002),

Archer Clive, International Organization. London. Allen \& Unwin Ltd, 1983. Internatiobnal of Organizations: Third edition clive archer. London : Routledg, 1992.

A Rahman Zainuddin, Kekuasaan dan Negara Pemikiran Politik Ibn Khaldun, Jakarta: PT. Gramedia, 1992.

al-Ghazalilmam, Al-Mustashfa, Juz I, Mesir: Al-Matba'ah alTijariyah al-Kubra, 1937

Ali Ridha Adnan al-Nahwi, Al-Syura La al-Dimukratiyah, Kairo: Dar al-Shahwah li al-nasyr, 1985.

Al-Mawardi, Al-Ahkam assulthaniyyah, Al-Qahirah: Dar Al-Hadits, 2006.

al-QardawiYusuf, Fiqh Daulah dalam Perspektif Al-Qur'an dan Sunnah, terj, Suhardi, Jakarta: Raja Grafindo, 1994.

An-NabhaniTaqiyuddin, AsySyakhsiyyah Al-Islamiyyah, jilid I, Beirut: Dar al-Ummah, 1994.

, Ad-Daulah alIslamiyah, Beirut: Dar alUmmah, terj, Umar Faruq dkk, Jakarta: HTI Press, 2014.

siyasiyah Li Hizbut-tahrir (Hizbut-Tahrir,1969). Terj. Oleh Shiddiq Al-jawi, 
Edi Sabara Manik, Hasanuddin; Strategi Membangun Kesadaran Penerapan

Syari'ah Islam Melalui Dakwah Ekstraparlementer

Konsepsi Poltik Hizbut-tahrir, Ghalia Indonesia: Jakarta, 2005.

Nizham fi al-

Islam, Beirut Libanon: Dar alUmah,terj Abu Amin dkk, Jakarta: HTI Press, 2015.

Pembentukan

Partai Politik Islam, Terj.

Zakaria, Labib, Jakarta:

HTIPress, Cet. II, 2007.

Membangun Sistem Ekonomi Alternatif Perspektif Islam, Terj. Nur khalish, Surabaya: Risalah Gusti, 1996.

Anonim, Mengenal Hizbut Tahrir dan strategi Dakwah Hizbut Tahrir, Terj.cet IV, Bogor: Pustaka Thariqul Izzah, 2010.

ApterDavid E, Pengantar Analisa Politik, Jakarta: LP3ES, 1996.

Arbi Sanit, Perwakilan Politik Di Indonesia, Jakarta: Rajawali,1985.

As'Ad Said Ali, Ideologi Gerakan Pasca-Reformasi: Gerakan Sosial Politik Dalam Tinjauan Ideologis, Jakarta:LP3ES, 2012.

at-TharablusiAbdullah, Perubahan Mendasar Pemikiran Sayyid Qutub, terj. M. Maghfur Wachid, Surabaya: Ibadah.Net, 2000.

Az-zuhailiWahbah, Fiqih Islam Wa Adillatuhu,Terj Jil.VIII, Jakarta: Gema insani \& Darul Fikir. 2011.

Bagong, Suryanto dan Sutinah (editor), Metode Penelitian Sosial, Jakarta: Kencana Prenada Media Group. 2005.

BagusLorens, Kamus Filsafat. Jakarta: PT Gramedia Pustaka Utama, 1996.
BudiardjoMiriam, Dasar-dasar IImu Politik, Jakarta: Gramedia Pustaka Utama, 2008.

Creswell John.W, Research Design Qualitative\&Quantitative Approaches, India: Sage Publications, 1994.

DahlRobert A, Rezims and Opposition, London: Yale University Press, 1973.

Daud Rasyid, Pembaharuan: Islam dan Orientalisme Dalam Sorotan, Jakarta: Usamah Press, 1993.

Dimyati Rifa'i (Penj.) Tantangan politik Negara Islam, Malang: Pustaka Zamzami, 2003.

DoufergMaurice, Pengantar IImu politik, diterjemahkan kedalam bahasa Arab oleh Sami Darubi dan Jamal Atasi (Daarul Jail, Beirut). Dalam buku Tijani Abd.Qadir Hamid, Pemikiran Politik Dalam AlQuran, Jakarta: Gema insane Press, 2001.

Endang Turmudzi dan Riza Sihabudin, (ed), Islam dan Radikalisme di Indonesia, Jakarta: LIPI Press, 2006.

Esposito.John L, (ed.), The Oxford Encyclopedia of The Modern Islamic World, New York: Oxford University Press, 1995.

Fathiy Syamsuddin Ramadhan A Nawiy, panduan Lurus Memahami Khilafah Islamiyyah Menurut Kitab Kuning, Jakarta: Wadi Press, 2013.

Hafidz Abdurrahman, "Hizbut Tahrir Masuk Parlemen Mengapa Tidak?" dalam Majalah Hidayatullah, Surabaya: April 2005.

HamidTijaniAbd.Qadir, Pemikiran Politik Dalam Al-Quran, 
Al-Fikra: Jurnal IImiah Keislaman, Vol. 16, No. 2, Juli - Desember, 2017 (233 268)

Jakarta: Gema insane Press, 2001.

HasanAbul, Muslim, Shahih Muslim, (Semarang: Toha Putra, t.th.)

HetwoodAndrew, Key Concept in Politicts,London: Macmillan Press, 2000.

Hizbut-Tahrir Indonesia, Partai Politik dalam Islam, Jakarta: HTI Press.2008.

Mengenal Hizbut Tahrir dan Strategi Dakwah Hizbut tahrir, Bogor: Pustaka Thariqul Izzah, Cet. III, 2009. a, Mengenal Hizbut Tahrir Partai Islam Ideologis, terj. Abu Afif dan Nur khalis, Bogor: Pustaka Thariqul Izzah, 2000.

b, Strategi Dakwah Hizbut Tahrir, terj. Abu Fuad dan Abu Raihan, Bogor: Pustaka Thariqul Izzah, 2000. c, Titik Tolak Perjalanan Dakwah Hizbut Tahrir. terj. Muhammad Maghfur, Bogor: Pustaka Thariqul Izzah, 2000.

HuwaidFahmi, Li al-Islam wa alDimukratiyah, Kairo: Markaz al-Ahram li al-Thiba'ah wa alNasyr, 1993

Ibnu Khaldun, Mukaddimah, terj, Masturi Ilham, dkk, Jakarta: Pustaka Al-Kautsar, 2001.

Ibnu Khaldun, Mukaddimah, terj. Jakarta: Pustaka Alkautsar, 2011.

Ihsan Samarah, Biografi Singkat Taqiyuddin al-Nabhani, Bogor: Al-Izzah Press, 2002. , Mafhum al-Adalah al-ljtima'iyah fi al-Fikri alIslami al-Mu'ashir, terj. Muhammad Shiddiq al-Jawi, (Bogor: Al-Azhar Press, 2003.
Ismail al-Wahwah, Dunia Membutuhkan Khilafah, Buletin al-Wa'ie, VII, edisi 131 September 2007.

lqbal, Hasan, Pokok-Pokok Materi Metodologi Penelitian Dan Aplikasinya, Edisi Pertama, Jakarta: Ghalia Indonesia, 2002.

John L. Esposito, (ed.), The Oxford Encyclopedia of The Modern Islamic World, New York: Oxford University Press, 1995.

M. Ali Dodiman, Memoar Pejuang Syari'ah dan Khilafah; Biografi Ringkas Tokoh senior Hizbut tahrir, Bogor: Al-Azhar Fresh Zone Publishing, 2012.

M. Din Syamsuddin, Etika Agama dalam Membangun Masyarakat Madani, Jakarta: Logos Wacana IImu, 2002.

M. R. Rasyid, Makna Pemerintahan, Tinjauan Dari Segi Etika dan Kepemimpinan, Jakarta: Yarsif Watampone, 1996.

M. Ridwan dkk, Kamus Ilmiah Populer, Jakarta:Pustaka Indonesia, 2005.

MahmudAhmad, Ad-Dakwah Ila alIslam, terj. Mahbubah, Bogor: Pustaka Thariqul Izzah, 2002.

MarbunMarcedes, Pengantar IImu Hubungan Internasional, Bandung: Rosdakarya, 2005.

Mochtar Mas'oed, IImu Hubungan Internasional: Disiplin dan Metodologi, Edisi Revisi, LP3ES: Jakarta, 1990.

Mohtar Mas'oed,dan Colin Mac Andrews, Perbandingan Sistem Politik, Yogyakarta: Gadjah Mada University Press, Cet. Ke-18, 2008. 
Edi Sabara Manik, Hasanuddin; Strategi Membangun Kesadaran Penerapan Syari'ah Islam Melalui Dakwah Ekstraparlementer

Muhammad Din Syamsuddin, Islam dan Politik Era Orde baru, Jakarta: Logos, 2001.

dalam , Etika Agama
Masyarakat Madani, Jakarta: Logos Wacana IImu, 2002.

Munawir Sjadzali, Islam dan Tata Negara, Ajaran, Sejarah dan Pemikiran, Jakarta: UI-Press, 1993.

RaisDhiauddin, Teori Politik Islam, Jakarta: Gema Insani Press, 2001.

RodhiMuhammad Muhsin, Tsaqofah Dan Metode Hizbut Tahrir Dalam Mendirikan Negara Khilafah Islamiyah, Jakarta: Al-Izzah , 2008.

Ronny H. Soemitro, Metodologi Penelitian Hukum Dan Jurimetri, Ghalia Indonesia: Jakarta, 1998.

Rosenthall.J., Islam in the Modern National State, Cambridge: University Press, 1965.

Rudy May Teuku, Administrasi dan Organisasi Internasional. Bandung. PT. Refika Aditama, 2005.

Syabab Hizbut Tahrir, Bagaimana Membangun Kembali Negara Khilafah, terj.: M.Ramdhan Adi, Bogor: Pustaka Thariqul Izzah, 2008.

Syamsuddin Ramadhan An-Nawiy, Panduan lurus memahami Khilafah Islamiyah, menurut Kitab kuning, Jakarta:WadiPress,2013.

Taufiq Adnan Amal, dkk, "Politik Syariat Islam" dari Indonesia Hingga Nigeria, Jakarta: Pustaka Alvabet, 2004.

Zainul Kamal, dkk., Islam Negara dan Civil Society ;Gerakan dan pemikiran Islam
Kontemporer, Jakarta:

Paramadina, 2005.

ZallumAbdul Qadim, Sistem Pemerintahan Islam,Terj.

Bangil: Al-Izzah, 2002.

Al-wa'ie, Khilafah Ajaran AhlusSunnah, No 180 1-31 Agustus 2015.

Al-Wa'ie, VII, Dunia Membutuhkan Khilafah, edisi 1-31 September 2007.

Bambang Setiawan, Sebuah Negara Praetorian Dalam Pijakan Ormas. Kompas, 10 mei 2006. 